\title{
International Cross-Listing: The Effects of Market Fragmentation and Information Flows
}

\author{
Richard Podpiera ${ }^{1}$ \\ April 2001
}

\begin{abstract}
We investigate the effects of market fragmentation and information flows in the case of stocks cross-listed on markets in Central Europe and London. First, we test for co-movement, interaction and error correction behavior between the local and London markets. Our results suggest that strong interactions exist between these markets, with the London market being slightly more important than the local one. The two prices of cross-listed stocks are cointegrated and pricing errors are corrected over a few days. These interactions suggest partial fragmentation. Second, we extend an earlier model to examine the impact of foreign listing on the variance of local returns. The focus of previous studies has concentrated almost exclusively on the return of cross-listed securities. The variance of returns has remained mostly unnoticed, even though some studies noted an increase of variance after the cross-listing. In our model, we introduce a new factor that influences return variance: tighter interaction with foreign markets as a consequence of cross-listing. Estimation results lend support to our model.
\end{abstract}

Abstrakt: Zkoumáme dopady fragmentace trhů a informačních toků $\mathrm{v}$ př́padě akcií duálně obchodovaných na trzích ve střední Evropě a v Londýně. V první části článku testujeme, do jaké míry se ceny na lokálním a londýnském trhu pohybují společně, zda jsou integrované, popř́ípadě zda existuje mechanismus napravování chyb. Naše výsledky ukazují, že mezi těmito trhy existují silné interakce a že londýnský trh je mírně důležitější. Ceny na domácím a londýnském trhu jsou kointegrovány a chyby $\mathrm{v}$ ocenění jsou napraveny v průběhu několika dní. Tyto interakce naznačují částečnou fragmentaci trhů. Ve druhé části jsme rozšíríili dř́vějš̌i model, abychom mohli zkoumat dopad duálního obchodování akcií na variabilitu jejich domácích cen. Předchozí studie se totiž zaměřovaly téměř výlučně na výnos duálně obchodovaných akcií, zatímco variabilita výnosů zůstávala většinou nepovšimnuta, i když některé studie upozornily na vyšší variabilitu na domácím trhu po zavedení duálního obchodování. V našem modelu zavádíme nový faktor, který vysvětluje variabilitu výnosů - těsnější interakci se zahraničními trhy jako důsledek duálního obchodování. Výsledky odhadů podporují náš model.

Keywords: cross-listing, information flow, order flow, return variance, market fragmentation

JEL Classification: G14, G15

\footnotetext{
${ }^{1}$ CERGE-EI, a joint workplace of Charles University and the Academy of Sciences of the Czech Republic, Prague. Correspondence to: CERGE-EI, P.O. Box 882, Politických vězn̆ů 7, 111 21, Prague, Czech Republic. E-mail: Richard.Podpiera@cerge.cuni.cz. I would like to thank Randall Filer, Jan Hanousek and Jan Kmenta for helpful comments. The usual disclaimer applies.
} 


\section{Introduction}

Cross-listing of securities has been increasingly popular in recent decades, with the number of ADR and GDR issues increasing rapidly. Indeed, even firms from transition economies with limited equity market experience have introduced their stock to the international equity markets in London or New York. With the growing popularity of cross-listing in financial markets, economic literature has started to pay closer attention to this phenomenon. ${ }^{2}$

The majority of previous studies have concentrated on the excess return connected with cross-listing. The second most important characteristic of a stock, its risk as measured by return variance, has been largely neglected. The present paper attempts to fill this gap. First, we investigate the information flows between markets for cross-listed securities and the degree of integration of the local and foreign markets. Second, we turn to the problem of local-return volatility. We extend an earlier model of Domowitz et al. (1998) and estimate it using data on stocks from Central Europe that are cross-listed on the London Stock Exchange. We explicitly include pricing errors between the local and London markets as a factor influencing the beliefs of market participants. Approximately half of the stocks in our sample allow us to estimate the effects of cross-listing directly, in an event-study manner; for the rest we estimate a simplified version of the model.

\footnotetext{
${ }^{2}$ For instance, over 115 depositary receipt programs, from over 30 countries, are listed on the London Stock Exchange.
} 
In the first step of our analysis, we attempt to determine whether and to what extent the information flows between local and foreign markets are important. For this purpose, we use the Granger causality framework and a cointegration/error-correction approach. By estimating these models we are, in fact, testing whether the two markets are integrated or fragmented. If the markets are integrated, in effect it is only one market with two trading venues, there will be only one price of two virtually identical assets (the payoffs of the stock and the GDR are basically the same). Of course, this does not mean that random fluctuations of the two prices cannot exist, creating temporary price differences. In an integrated market setting, however, such price differences should not exhibit any systematic pattern and should be quickly corrected - mostly during the same trading day. Systematic patterns in daily data suggest that the markets are fragmented.

A related question, which we also address and which is important for the second step in our analysis, is whether either of the markets dominates the other in terms of new information discovery. The local market might have superior access to information about local firms, at least in terms of timing, but the foreign markets are more developed and much more capitalized and thus theoretically their shocks might spill over to the local markets. Another related question is whether profitable arbitrage opportunities exist and, if they do, how quickly they are corrected.

In the second step, we focus on the return volatility of cross-listed stocks. As already mentioned, few of the studies that dealt with cross-listed shares explicitly examine the behavior of return variance. Most recently, Domowitz et al. (1998) and Foerster and Karolyi (1999) report that the variance of returns increased after the cross listing. In our view, which we formalize and explore in this paper, return variance of cross-listed 
securities on a partially fragmented market can be decomposed into three components. ${ }^{3}$ The first is the baseline volatility, which is determined by the realization of new information and market frictions unrelated to the other two factors. The second is the magnitude and characteristics of order flow (or, in other words, liquidity) and the third is foreign market volatility. This third factor is transferred to the local price of the crosslisted security through pricing errors and utilization of arbitrage opportunities by investors. The first two factors were examined by Domowitz et al. (1998) using data on Mexican equities; however, these two factors did not explain the increase of variance after GDR listing.

We use data on stocks from three markets in Central European countries in transition. Emerging capital markets in transition economies are often flawed by problems of low liquidity, insufficient regulation or market fragility. These problems are arguably more serious compared with those in other emerging markets that have developed over a longer time period (for instance, in Mexico). Since we explore the impact of market fragmentation, these markets appear to be more suitable for our analysis than other, more advanced, emerging markets and certainly are more suitable than developed markets. It is also advantageous to use stocks from three different markets, even though international portfolio investors often perceive them as being one regional market. The capital markets in these three countries have experienced quite different development over the past ten

\footnotetext{
${ }^{3}$ Since ideal markets do not exist in the real world, all real data will come from markets that are at least slightly fragmented. It is thus somewhat surprising that Domowitz et al. (1998) attempt to test for market integration when they were unable to obtain price information from both local and foreign markets for the stocks in their sample. It appears unlikely for two markets to be integrated when prices from one of the markets are not easily available to a large population of market participants.
} 
years and have different structures. Using data from three countries thus allows us to lower any potential flaw caused by idiosyncratic features.

We bring evidence from three emerging capital markets (the Czech Republic, Hungary, and Poland), whereas most previous studies on cross-listing dealt with developed markets (U.S., U.K., Canada, and Japan), which are large and liquid. ${ }^{4}$ All three countries, though to different degrees, have significantly relied on foreign investors to finance the transition toward a market economy. On the part of foreign investors there has been substantial interest, primarily because the three countries are the most developed among the transition countries, are now members of NATO and are viewed as being on the fast track for EU membership. It should come as no surprise then that foreign investors have played an important role in these capital markets.

As for related literature, the study by Domowitz et al. (1998) is most closely related to ours. Domowitz et al. investigated the effect of order flow migration using data on Mexican shares. They showed that the effect of cross-listing depends on the quality of inter-market information linkages. On one hand the domestic market experiences order flow migration to the foreign market where the stocks are newly listed, but on the other hand, cross-listing could improve market quality in terms of spreads, precision of public information and overall liquidity of the stock. The realization of these benefits, however, hinges on the degree of integration of the two capital markets. Domowitz et al. deal with order flow migration, but they do not recognize that foreign market volatility becomes a stronger factor influencing local market volatility when local shares are cross-listed abroad. We extend their work to explicitly include the volatility of prices on the foreign 
market by considering the reaction of market participants to pricing errors. As we have already mentioned, Domowitz et al. found that volatility increased after international cross-listing. Indeed, virtually all the securities they study experienced a rise in volatility after the cross-listing and they are not able to explain this rise by liquidity changes. ${ }^{5}$

One of the earliest relevant studies on dually listed stocks dates back to the late seventies and was authored by Garbade and Silber (1979), who analyzed the short-run behavior of dually listed equities, that is, stocks traded on the New York Stock Exchange and the regional stock exchanges. These authors introduced the concept of dominant and satellite markets. If a particular security is traded on two markets, say A and B, under imperfect market integration the price adjustment can be characterized in two ways. First, the adjustment to mispricing might be symmetric, that is, the speed of adjustment of prices in market A is the same as the speed of adjustment of prices in market B. On the other hand, prices in one market (for instance A) may usually or always adjust to prices in the other market (B); then, market B is dominant and market $\mathrm{A}$ behaves like a satellite.

Lieberman, Ben-Zion and Hauser (1999) examine the price behavior of stocks dually listed in Israel and the U.S. by using an error-correction approach. The authors found that the price time series of dually listed securities are cointegrated, arbitrage opportunities are generally not available, and the domestic market mostly emerges as dominant, while the foreign market behaves like a satellite. Hauser, Tanchuma and Yaari (1998) used data on several stocks listed on both the Tel Aviv Stock Exchange and the NASDAQ in order to investigate the information transmission between these two markets. Two alternative

\footnotetext{
${ }^{4}$ Wahab et al. (1992), Kato et al. (1991) or Werner and Kleidon (1996) to name just a few.
} 
tests for causality, both based in essence on the Granger (1969) idea were used. Their conclusion was that the price causality is unidirectional from the domestic market to the foreign market. Murphy and Sabov (1995) explored the pricing of Hungarian stocks unofficially quoted in Vienna. Their study uses data from a truly embryonic phase of the development of Hungarian capital markets and thus their results cannot be directly compared to ours.

As mentioned earlier, there exists a rather rich literature dealing with the impact of crosslisting on the (required) return of a stock. Theoretical models, for instance Alexander et al. (1987), suggest that cross-listing should lead to temporary excess returns, which are justified by the fact that cross-listing removes existing market segmentation. Empirical results, however, have not been completely persuasive. Domowitz et al. (1995) found that excess returns are insignificant around the GDR (ADR) listing, while Jayaraman (1993) found significant gains only for Japanese firms. Alexander et al. (1988) found positive abnormal returns prior to the cross-listing, but they also observed negative returns after the cross-listing. More recently, Miller (1999) examined the stock price reaction to international dual stock listing across a broad sample of countries and focused on the date of the dual-listing announcement rather than the actual listing date. His findings suggest that the excess returns are indeed significant.

Overall, theoretical studies suggest that the cross-listing will lead to excess returns if the two markets are not integrated. However, there are also possible drawbacks, which arise when the two markets are fragmented, i.e., pricing information is not readily available or

\footnotetext{
${ }^{5}$ Domowitz et al. (1998) also cite other studies which document an increase in return variance following international cross listing: Jayaraman et al. (1993) and Karolyi (1996).
} 
there are other barriers to transfer of information. Then, order migration might decrease local market quality as suggested by Domowitz et al. (1998). Moreover, as we suggest, the transfer of foreign market volatility might increase the volatility of local returns. This might be particularly important in the case of emerging markets with relatively low liquidity that tend to be vulnerable to transfer of fluctuations from developed markets.

To sum up, the contribution of this paper is threefold. First, we use Granger causality and cointegration/error-correction models to draw conclusions about market integration or fragmentation. ${ }^{6}$ Second, we extend the Domowitz et al. (1998) model to include the effects of foreign market volatility and focus on the variability of local returns after GDR listing. Third, we are using data from three emerging markets, for which the abovementioned volatility and order migration effects should be important. Such data has not been used previously, as most previous papers dealt with developed markets.

\section{Data Description}

We use data from three equity markets in Central Europe: the Czech Republic, Hungary and Poland. The Czech Republic employed coupon privatization when privatizing large firms, which led to widely dispersed ownership of shares and fast development of the equity market, at least in terms of market capitalization and the number of traded shares. The regulation of the market and especially the protection of minority shareholder rights lagged significantly behind. Investor confidence was damaged by several cases of fraud and the Czech capital market gradually came to be regarded as an insider market. Since many shareholders who received shares in coupon privatization sold out and there have 
been neither strong domestic institutional players nor broad small-shareholder participation, the Czech market has been to a large extent dependent on foreign investors.

Poland took a different approach. It started with strict regulation and a small number of companies on the stock exchange, but the market developed rather rapidly and attracted a number of initial public offerings. Also, Poland became to a large extent a retail market, with a large number of small shareholders. Hungary sold a large number of its large firms to foreign investors, which improved its business climate significantly. The number of firms on the exchange was smaller compared to the Czech Republic, but the investment sentiment was better also, because international investors trusted the foreign owners of companies whose shares were traded on the exchange.

The different levels of capital market regulation, combined with differences in economic development, led to a very large variation in returns of the three markets. In early June 1994, when our sample starts, the Czech market index PX-50 stood at approximately 650 points. Six years later, in mid-2000, it was actually lower, at 580. The Polish index WIG20 performed considerably better, as it grew from approximately 1,000 points in early June 1994 to approximately 2,000 points in June 2000. The Hungarian index BUX jumped from 1,600 points to some 9,000 points over the same time period. ${ }^{7}$

In our sample, there are 3 companies from the Czech Republic, 10 companies from Hungary and 9 companies from Poland. All of these have their stocks dually listed on the

\footnotetext{
${ }^{6}$ To our knowledge, these models have not been used in this way previously.

${ }^{7}$ All three indices are weighted by market capitalization. Hungary and Poland experienced higher inflation than the Czech Republic during the mentioned time period, but this does not explain the difference in index returns. If we take into account the development of consumer inflation since 1994, the PX-50 fell to 400 points, the WIG20 index stayed virtually flat at 975 points and the BUX index increased to 3,830 points.
} 
local market and in London (at the London Stock Exchange) in the form of Global Depositary Receipts (GDR). ${ }^{8}$ Basic information is depicted in Table 1.

\section{$<$ Table 1 can be found in the Appendix $>$}

Table 1 reveals that the companies come from a rather diverse range of industries - from financial services like banking or leasing to metal and miscellaneous production. The companies are diverse also in terms of their market capitalization, which varies from just over 30 million USD for Polish Mostostal to almost 10 billion USD in the case of Polish telecom. In fact, telecom companies in all three countries are the most capitalized in both relative (compared to other stocks in the country) and absolute (compared to all stocks in our sample) terms. The average market capitalization stands at 1.4 billion USD.

The stocks are diverse also in terms of the length of time of the GDR listing and the way they were introduced to the capital market. The stock of some companies was put on the capital market as a result of coupon privatization (for instance Komerční banka or Český Telecom) while other companies were introduced on the market as IPOs rather recently (e.g. Agora or Europejski Fundusz Leasingowy). In some of these cases, the stock was introduced simultaneously to the local and London markets, which prevents us from performing an analysis of the impact of cross-listing - the pre-GDR data simply does not exist. In other cases, even though the stock traded on the local market prior to its introduction to London, the time series prior to cross-listing are too short for us to be able

\footnotetext{
${ }^{8}$ A number of shares from the three countries are also listed on stock exchanges in Germany and Austria. However, the liquidity on these exchanges is too low for us to use the prices for estimation. One of the problems is that with low liquidity it might not be profitable for investors to engage in arbitrage between the markets as long as the price difference is not very large. Also, London is more important as a financial center than Frankfurt or Vienna and the shocks from developed markets are arguably more visible there compared with Frankfurt or Vienna. Moreover, most international investors and brokers that are active in Central Europe are based in London.
} 
to analyze the impact of cross-listing. Overall, we have 10 stocks out of the total 22 for which data is available both before and after the cross-listing. ${ }^{9}$ On average, then, we have 984 days of local trading and 693 days of GDR trading for each stock. Komerční banka started to trade the earliest on its local market, in June 1993, while Europejski Fundusz Leasingowy has been floated most recently, in March 2000.

The shares of the companies in our sample are traded on the local stock exchanges in Prague, Budapest and Warsaw. All three exchanges are relatively modern in that they rely on computer networks as the means of communication during trading. The role of physical presence of traders on the floor and open outcry auction has been eliminated. On the Prague Stock Exchange, the most important change occurred in May 1998, when a system of market-makers who quote firm prices for the most liquid shares was created (all 3 Czech stocks in our sample qualify as being among the most liquid and are thus traded in this system). ${ }^{10}$ In Budapest, a new computerized trading system that allows remote access of traders was introduced in 1998. The system, which operates without a market maker or specialist, has two phases: a single price auction and a continuous auction. All the Hungarian stocks in our sample are included in the highest market category (A). ${ }^{11}$ In Warsaw, there are also two trading systems: single price auction (batch auction) and continuous trading. There is a specialist, but his function is to a large extent

\footnotetext{
${ }^{9}$ For the remaining 12 stocks, we estimate a simplified model.

${ }^{10}$ The Prague Stock Exchange has, in fact, three different trading systems and shares are divided into groups according to their liquidity. The least liquid shares are traded only in a batch auction (single price). For more liquid shares, the batch auction is followed by continuous trading and the most liquid shares are traded in the market-maker system.

${ }^{11}$ In this category, the listing requirements call for the company's market capitalization to exceed 10 billion HUF (roughly 35 million USD). In addition, the number of shareholders should be greater than 1,000 , the company must have at least 3 completed and audited business years and the most recently audited business year must show profit.
} 
administrative; he determines the price in the batch auction in accordance with pre-set rules. ${ }^{12}$ The specialist may balance the order flow by trading on his own account, but he is not obliged to quote firm prices. The division of shares into trading groups is, again, driven by their liquidity. The most liquid shares started to be gradually included in continuous trading in the second half of $1996 .{ }^{13}$ All the Polish shares in our sample trade continuously.

As for the London trading venue, GDRs on the shares are traded on the international segment of the London Stock Exchange (also known as SEAQ International). In this system, market makers key their bid and offer prices directly into the central computer system and investors contact the market makers by telephone to execute a trade. As for the settlement and transfer, once the investor and market maker execute their trade, they decide when settlement will take place. The GDRs are depositary receipts denominated in U.S. dollars and issued by a bank (in our sample, most often by the Bank of New York) that holds the underlying shares. The depositary takes care of voting at the general meetings, dividend payments, etc. All the GDRs are company-sponsored, which means that the company itself contracted the depositary to perform the depositary services. Most of the GDRs in our sample are so-called REG S shares, which means that they are to be traded only by qualified institutional investors.

\footnotetext{
12 The price-setting rules in the batch auctions are very similar across the three markets. Given the submitted orders, the aim is to maximize the trading volume, minimize the excess supply or demand, and minimize the price change from the previous trading session.

${ }^{13}$ By the end of 1999, shares of 99 companies were being traded continuously. Trading units in continuous trading (lots) usually have the value of several thousand zloty (1 USD = roughly 4 zloty). They are thus smaller than the lots in the Czech market-maker system (there, trading units average around 50 thousand USD).
} 
Since we are exploring the information flows between the local and London markets, it is important to measure the prices simultaneously. Otherwise, any results suggesting the existence of information flows between markets might be caused simply by the fact that prices are measured at different times during the trading day. ${ }^{14}$ For instance, if markets in Central Europe closed prior to the London market, new information might appear during the time when only the London market was in operation. Estimation results might then suggest that the local markets follow the movement of the London market, even though there is no such process in reality. Fortunately, this is not a serious problem in our case. Even though quotations can be inserted into the SEAQ-I system from 7:30 to 17:15 GMT (which is 8:30-18:15 local time in the three countries under consideration) and trading ends between 16:00 and 16:30 at the local exchanges, our London closing prices are recorded at the time of local market close.

\section{Information Links Between Markets}

\subsection{Models}

As the first step in our inquiry about the role of information flows and local market volatility, we estimate two models: Granger causality and cointegration/error-correction models. These should help us determine whether the two markets, local and London, are integrated or fragmented.

\footnotetext{
${ }^{14}$ I would like to thank Randall Filer for bringing this point to my attention.
} 


\subsubsection{Information Flows: Granger Causality}

First, we estimate the Granger causality model in order to find out what the direction of information flows is and whether any market, local or London, can be viewed as dominant in terms of information discovery. In fact, both could play the role of a dominant market. The domestic market is closer to the sources of information about the companies, but foreign investors are important players on the local markets and might react to the development of global capital markets and thus influence the local market.

The model is in the usual Granger (1969) causality framework, which allows us to examine the co-movements of two time series. One time series is regressed on its own lagged values and on the lagged values of the other time series. In general, if we denote the two time series under study as $\mathbf{x}$ and $\mathbf{y}$, the model to be estimated takes the form

$$
\begin{aligned}
& x_{t}=\sum_{i=1}^{p} \alpha_{i} x_{t-i}+\sum_{j=1}^{p} \beta_{j} y_{t-j}+\varepsilon_{t} \\
& y_{t}=\sum_{i=1}^{p} \gamma_{i} x_{t-i}+\sum_{j=1}^{p} \delta_{j} y_{t-j}+\xi_{t}
\end{aligned}
$$

We say that $\mathrm{x}$ Granger-causes $\mathrm{y}$ if the lagged values of $\mathrm{x}$ in the regression of $\mathrm{y}$ on lagged $\mathrm{y}$ and $\mathrm{x}$ are statistically significant. This means that lagged values of $\mathrm{x}$ contain relevant information for the current value of y. In our specification, we test whether the coefficients $\gamma$ are jointly significantly different from zero, and symmetrically for the hypothesis that y Granger-causes x. Overall, we can find four possible outcomes: two cases of unidirectional causality ( $\mathrm{x}$ causing $\mathrm{y}$ or $\mathrm{y}$ causing $\mathrm{x}$ but not vice versa), no causality, and causality running both ways. In our specific case, the two time series are 
the returns of the local stock and its GDR (converted to be expressed in terms of one currency, at the current market exchange rate).

Returns are computed as percentage price changes. We can thus have causality (and information) flowing from the local market to London only or vice versa. The other two possibilities are either causality in both directions (then we cannot say what market is dominant) or no causality. It should be noted that the evidence of causality in either or both directions suggests that the markets are fragmented. This is due to the fact that we use daily data and we would expect the pricing differences to disappear quickly. In the no-causality case, we cannot reject the hypothesis that the markets are integrated and that new information is compounded into prices simultaneously at the two trading venues. However, it might also be the case that the two price series are unrelated. This possibility is addressed in the following sub-section, where we test the cointegration of the two time series and estimate an error-correction model.

We use the basic OLS estimator, but with a correction for heteroscedasticity; stock price time series, similarly to many other financial time series, are known to be prone to changing variance. ${ }^{15}$ We use the standard White (1980) approach. In order to test for the joint significance of the lagged terms, we use the usual F-test, that is, we test the restriction that the coefficients of the lagged terms are jointly equal to zero. ${ }^{16}$ The optimal number of lags ( $\mathrm{p}$ ) was determined according to the standard Akaike and Schwarz Bayes Information Criteria.

\footnotetext{
${ }^{15}$ Below, we show that there are no unit roots in the return time series (as opposed to time series of prices) and we can therefore use the OLS estimator.

${ }^{16}$ It should be noted that as the standard errors are corrected for heteroscedasticity, the F-test is not valid strictly.
} 


\subsubsection{Existence and Persistence of Arbitrage Opportunities: an Error Correction}

\section{Approach}

In this section, we inquire into the existence of arbitrage opportunities and their persistence. First we create the mispricing series - that is, the difference between the price on the local market and in London - and compute its basic statistical properties. We use the current market exchange rate to make prices on the two markets comparable.

Then we test for the level of integration of the price time series. We need to ascertain the degree of integration in order to proceed with the cointegration and error-correction models. In our case, one would expect (and this indeed turns out to be the case) that the price time series will not be stationary but their first differences will be stationary. This means that the domestic and foreign prices are both integrated of the order I(1). We use the augmented Dickey-Fuller (ADF) test in order to test for the degree of time series integration. For any time series, let us denote it $\mathbf{y}$, this test amounts to running the regression

$$
\Delta y_{t}=\mu+\gamma y_{t-1}+\sum_{j=1}^{p-1} \delta_{j} \Delta y_{t-j}+\varepsilon_{t}
$$

and testing whether the coefficient $\gamma$ is significantly different from zero. The null hypothesis is that this coefficient equals zero, which means that there is a unit root in the time series $\mathbf{y}$. Rejecting the null hypothesis allows us to conclude that the time series is stationary. ${ }^{17}$

\footnotetext{
17 Also when conducting the ADF test, the optimal number of augmenting lags (p) was determined according to the Akaike and Schwarz Bayes Information Criteria. We also considered the significance of the individual coefficients when deciding about the lag length.
} 
After testing stationarity, we proceed to estimate the possible cointegration relationship between the local and London prices and based on the results, we formulate the errorcorrection model. First we estimate the cointegration regressions:

$$
1_{\mathrm{t}}=\alpha_{1} \mathrm{UK}_{\mathrm{t}}+\varepsilon_{\mathrm{t}}
$$

and

$$
\mathrm{UK}_{\mathrm{t}}=\beta_{1} 1_{\mathrm{t}}+\xi_{\mathrm{t}}
$$

where 1 and UK stand for the prices on the local and London markets. We then test for stationarity of the residuals from the regressions by using the augmented Dickey-Fuller test again. If we can reject the null hypothesis of a unit root in the residuals from the above regressions, that is, if the residuals are $\mathrm{I}(0)$, we can conclude that the time series are cointegrated. The coefficients $\alpha_{1}$ and $\beta_{1}$ express the equilibrium relationship between the two variables and can be used to formulate the error-correction model.

One would expect, naturally, that the two prices should be the same (after all, the two securities are virtually identical), so the coefficients $\alpha_{1}$ and $\beta_{1}$ would be equal to one and the difference in prices would then be the error (the deviation from the long-term equilibrium relationship). We estimate both variants of the error-correction model, the local return as dependent variable

$$
\Delta \mathrm{L}_{\mathrm{t}}=\lambda\left(\alpha_{1} \mathrm{UK}_{\mathrm{t}-1}-\mathrm{L}_{\mathrm{t}-1}\right)+\delta_{1} \Delta \mathrm{UK}_{\mathrm{t}}+\pi_{1} \Delta \mathrm{IXL}_{\mathrm{t}}+\varepsilon_{\mathrm{t}}
$$

and the London (GDR) return as the dependent variable

$$
\Delta \mathrm{UK}_{\mathrm{t}}=\theta\left(\beta_{1} \mathrm{~L}_{\mathrm{t}-1}-\mathrm{UK}_{\mathrm{t}-1}\right)+\delta_{2} \Delta \mathrm{L}_{\mathrm{t}}+\pi_{2} \Delta \mathrm{IXUK}_{\mathrm{t}}+\xi_{\mathrm{t}}
$$

where IXL and IXUK stand for the market index in the local capital market and in London. We generally use the most widely quoted indices, which all employ market 
capitalization weighting: PX-50 for the Czech Republic, BUX for Hungary, WIG20 for Poland and FTSE100 for the U.K. market. The two parameters of primary interest ( $\lambda$ and $\theta)$ are those at the error term. These parameters reveal the way the time series react to the short-term deviations from the long-term equilibrium relationship. Market efficiency and the no-arbitrage theorem do not exclude the possibility that random factors cause the two time series to diverge from their equilibrium relationship. Such random fluctuations, however, should be quickly corrected by arbitrage. Thus, arbitrage opportunities might exist, but they should not persist over a long period of time. The fact that we allow the error-correction coefficients ( $\lambda$ and $\theta$ ) to be different also offers an insight into the dominant-satellite relationship between the two markets. If a mispricing arises, the satellite market would be expected to move faster toward the price on the other market than vice versa.

We use the OLS estimator for testing the unit roots and cointegration. For the errorcorrection model, we use the White (1980) heteroscedasticity-consistent estimator again. It should be noted that we faced the endogeneity problem when estimating the errorcorrection model in both directions - equations (5) and (6) form, in fact, a system of equations. We had to instrument for the contemporaneous price change on the other market $\left[\Delta \mathrm{UK}_{\mathrm{t}}\right.$ in equation (5) and $\Delta \mathrm{L}_{\mathrm{t}}$ in equation (6)] by its lagged value and by the change in the market index on the same market $\left[\Delta \mathrm{IXUK}_{\mathrm{t}}\right.$ in equation (5) and $\Delta \mathrm{IXL}_{\mathrm{t}}$ in equation (6)]. 


\subsection{Estimation Results}

\subsubsection{Results of Granger Causality Estimation}

We estimated the Granger causality model with different lag lengths (from 1 to 6 ) and, as already mentioned above, used the Akaike and Schwarz Bayes Information Criteria when choosing the optimal number of lags. The optimal number of lags varied between 2 and 6 for individual stocks, with 3 and 4 being the most frequent lag length. However, our results were not sensitive to the specification of the model.

\section{$<$ Table 2 can be found in the Appendix $>$}

The results suggest that there exist strong information flows between the local and London markets. In most instances we were able to reject the null hypothesis of no Granger causality. In fact, we were able to reject the null hypothesis in 20 out of the 22 instances for London to local market causality and in 14 out of the 22 instances for the causality from local market to London. Moreover, most of the rejections were at the $1 \%$ significance level. Overall, we found that in approximately half of the cases (12 out of 22), the causality ran in both directions; the London market appears to be more important on the whole, even though there are instances in which we observe a unidirectional causality from the local market to London.

Our results confirm that the development of the London market is important for the local equity markets in Central Europe and also, though to a somewhat lesser extent, the development on the local markets influences the trading of the GDRs in London. It is interesting to note that not only the F-test rejects the null hypothesis of no causality and allows us to conclude that the lagged price changes on the other market are jointly 
different from zero, but also many of the coefficients for individual lagged changes are highly significant (and, in line with expectations, they are virtually all positive: higher price in London implies higher price on the local market and vice versa). ${ }^{18}$ Indeed, in some instances lagged changes on the other market retain explanatory power for the returns on the other market for four or five days. This suggests that the markets are fragmented, since if there was indeed only one integrated market with two trading venues - local and London markets - prices would adjust very quickly and we would not be able to observe such a prolonged adjustment. ${ }^{19}$

\subsubsection{Results of Error-Correction Model Estimation}

First we computed the basic statistics for the mispricing series: the difference between the local price and the London price (which was converted to local currency). Taking the simple average over the sample period for each stock yielded values between minus $4.4 \%$ and plus $4.4 \%$. If we then took the average over all stocks, the mispricing would be equal to approximately zero; the positive and negative deviations would cancel out. This is not surprising and suggests that there is a long-term parity relationship between the local and London price. A better view of the magnitude of mispricing, however, is to examine the absolute value of the price deviations, since it does not matter, from the arbitrage point of

\footnotetext{
${ }^{18}$ Information on the individual coefficient estimates is presented in Table 7 in the Appendix.

${ }^{19}$ The approach presented above, looking for causality and market interaction in prices when both are expressed in a common currency (local or USD) basically assumes the arbitrage view of the problem: prices expressed in a common currency should move together since otherwise arbitrage opportunities would exist. The potential problem of this approach is that it introduces an additional source of variation, the exchange rate, into the analysis. If one wanted to focus purely on the information-driven co-movements in the two prices (information about the stock only), he or she might use the original time series, that is, without putting them into one currency (and then assume that the exchange rate movements are not correlated with news relevant for the stock's value). In our case, though, this problem does not affect the result. We have also estimated Granger causality also with the original GDR prices in USD and the
} 
view, in what direction the pricing difference occurs. Arbitrage can be executed in both directions.

If we inspect the series of absolute value deviations, we see that the average mispricing varies from $0.6 \%$ for Český Telecom to $5.4 \%$ for Polish KGH, with the average being $2.0 \%$. There is a weak tendency for the stocks with higher market capitalization to have a lower degree of mispricing. Overall, despite the fact that the two time series appear to be reasonably close, there might be room for profitable arbitrage. ${ }^{20}$

\section{$<$ Table 3 can be found in the Appendix $>$}

We have seen both positive and negative average returns among the stocks in our sample, with the average being slightly positive. For the ten stocks for which we have enough observations prior to the GDR listing, we have computed the volatility of local returns (volatility defined as the standard deviation) both prior to and after the GDR listing. In our sample, for 7 out of 10 stocks volatility increased after the GDR listing. The three markets under consideration were developing quite rapidly and the increase of volatility might be caused simply by changes of volatility on the market level. We thus compared the changes of volatility of the cross-listed stocks with the change of volatility of the market indices by using the variation coefficients (details can be found in Table 8 in the Appendix). It also turns out that in relative terms the volatility of cross-listed stocks increased: for 7 out of the 10 stocks, the variation coefficient either increased more or

conclusions on causality were virtually identical (even though the significance levels were higher and the number of statistically significant parameters was lower).

${ }^{20}$ We do not have precise estimates of transaction costs, but these declined dramatically over the past several years. Fierce competition for order flow decreased the commissions for the most liquid securities to several tens of basis points. 
decreased less than the volatility of the market index. ${ }^{21}$ Overall, our data confirm the findings of the previous studies we cited above, which suggest that the volatility of local returns is higher after GDR listing.

Table 4 depicts the results of unit root tests. In the vast majority of cases we were unable to reject the null hypothesis of a unit root for the price time series. This holds for prices both on the local market and at the London Stock Exchange. On the other hand, when we took first differences of the prices, we were able to reject the null hypothesis for almost all series. We thus concluded that most prices are integrated of the order I(1). In fact, for 19 out of the 22 stocks in our sample, we were able to conclude that both local and London prices are I(1). As for the remaining three stocks, for two of them we had already rejected the null hypothesis for the original price time series (and thus concluded that it was stationary) and for one stock - Europejski Fundusz Leasingowy - even the first differences were not stationary. In this last case, though, the results were most likely influenced by the low number of observations.

\section{$<$ Table 4 can be found in the Appendix $>$}

With two time series, both I(1), we can test for their cointegration. The regression of one price time series on another yields an estimate of the equilibrium relationship between the two time series. The results confirm the expectation that the coefficient should be close to one, that is, the two prices should be identical. The coefficients indeed do not differ from one and are highly significant. We report only the results of the regression of the local

\footnotetext{
${ }^{21}$ It should be noted that some of the cross listed stocks are members of the market indices we use as a representation of the overall market. This, however, is not a problem in this case. The difference in volatility changes between these stocks and the market index is simply due to the volatility of other stocks that were not cross listed.
} 
price on the GDR price in Table 4, but the results of running the regression in the other direction were almost identical. We conclude that in almost all cases the two price time series are cointegrated with the cointegration coefficient (long-run equilibrium relationship) being close to one.

The existence of two cointegrated time series allows us to estimate the error-correction model. The results can be found in Table 5 .

\section{$<$ Table 5 can be found in the Appendix $>$}

Our results confirm the existence of an error-correction mechanism between the local and London prices. The error term, the difference between the two prices, is significant in all 19 cases for the regression with GDR price change as the dependent variable and for 15 out of 19 cases with local price as the dependent variable. ${ }^{22}$ This implies that the existence of mispricing induces price changes that work to correct such mispricing. The error-correction estimates also correspond to the above results of Granger causality, which suggested that new information is realized on both markets and thus there is no pure dominant-satellite market relationship. Here, both prices react to the pricing error and the coefficients are similar in magnitude. In fact, the average of significant errorcorrection coefficients amounted to 0.35 for the change of local price as dependent variable and it stood at 0.50 for the change of GDR price as the dependent variable. Thus, the error-correction mechanism appears to be roughly symmetric. While there are mostly small differences between the coefficients for the two directions of error correction, substantial differences exist between countries. In the case of the companies from the

\footnotetext{
${ }^{22}$ We do not estimate the error-correction model for the 3 stocks for which we were not able to conclude that both local and London prices are I(1).
} 
Czech Republic and Poland, the error-correction coefficients average out to approximately one third, while Hungary's average coefficient is close to $60 \%$.

The main conclusion we draw from the results of estimating the error-correction model is that the local markets indeed react to the mispricing. Since the error-correction term was significant in the vast majority of cases, this conclusion is rather strong.

\section{Cross-listed Security on a Fragmented Market}

\subsection{Model}

Our model is based on the framework used by Domowitz et al. (1998), who examined cross-listing in terms of its impact on order flow. Domowitz et al. argue that when price information is freely available and the markets are integrated, cross-listing results in an improvement of market quality. Cross-listing induces participation of foreign investors who would otherwise not trade. Thus, liquidity improves, with the positive effects of lowered spreads and increased precision of public information; and these in turn increase liquidity by attracting even more investors. If information linkages are very poor (the markets are completely fragmented), cross-listing decreases liquidity and increases volatility in the local market as diversion of informative order flow decreases the quality of the domestic market. If information linkages are imperfect (the partial fragmentation case), the overall result is unclear. Higher intermarket competition may decrease domestic spreads, but order flow migration lowers domestic market liquidity and increases price volatility. 
The problem that we would like to bring attention to is that cross-listing of securities brings higher excess returns when the two markets are segmented, that is, if there are some barriers to investment. Such markets, though, will also tend to be fragmented, which induces the adverse effect of order flow migration. Also, errors in pricing between the local and foreign markets emerge as a new source of local price volatility. It thus appears that there will be a tendency for securities from fragmented markets to obtain cross-listing, which induces the negative effects of increased local market volatility after cross-listing.

While Domowitz et al. do not make the assumption of market integration or fragmentation, but rather attempt to determine the degree of fragmentation from their estimates, we assume that the markets are to some extent fragmented. We have two reasons for making this assumption and thus focusing on and developing the intermediate case between complete integration and complete fragmentation. First, the above estimates of Granger causality and cointegration models suggest that our markets are indeed fragmented. Second, since traders on the local market are unable to observe the London order flow, it appears that complete integration is impossible. ${ }^{23}$ In any case, if we introduced coefficient restrictions, our model could accommodate complete integration as well.

The focus on the partial fragmentation case allows us to add an important component into the Domowitz et al. framework, the volatility induced by market fragmentation. Intuitively, random shocks and the realization of information cause the price on the

\footnotetext{
${ }^{23}$ It is interesting to note that Domowitz et al. (1998) faced virtually the same setup with their Mexican data - foreign order flow was not observable either - and their results were indeed consistent with partial fragmentation.
} 
foreign market (in our case London) to be different from the price on the local market. Investors, as well as market markers, observe this difference and react accordingly when setting the quotes and making investment decisions. There thus exists another factor, the difference of prices in the two markets, that influences returns and possibly increases local market volatility. The importance of this factor will depend on the degree of fragmentation of the two markets and on the significance of information realized on the foreign market.

Also, formally our model starts from the Domowitz et al. (1998) framework. ${ }^{24}$ Consider a stock trading on local and foreign markets. Both domestic and foreign investors are allowed to trade the stock on both markets. ${ }^{25}$ The arrival of domestic and foreign investors is governed by independent Poisson distributions. The combined arrival intensity at the local market is denoted by $\theta$. We assume that investors arrive consecutively. Let $x_{k}$ denote the order of the trader $k$ who arrived at the market at time $t_{k}$. The variable $\mathrm{x}_{\mathrm{k}}$ can take three values: +1 if the order is a buy, -1 if the order is a sell and 0 if the trader who arrived chose not to trade.

Following Glosten and Milgrom (1985), we assume unit trade size and we also assume that the local price the trader faces is

$$
\mathrm{p}_{\mathrm{k}}\left(\mathrm{x}_{\mathrm{k}}\right)=\mu_{\mathrm{k}}+\mathrm{sx}_{\mathrm{k}}
$$

\footnotetext{
${ }^{24}$ Where possible, we retain the notation of the original Domowitz et al. (1998) paper to facilitate easy comparison of the models.

${ }^{25}$ This is satisfied for the three countries we consider.
} 
where $\mathrm{s}$ represents the order processing component of the spread and $\mu_{\mathrm{k}}$ denotes the expected value of the asset from the market-maker's point of view at the time $t_{k}$ (just before order $\mathrm{x}_{\mathrm{k}}$ arrives). The development of the stock's expected value is governed by

$$
\mu_{\mathrm{k}}=\mu_{\mathrm{k}-1}+\lambda \mathrm{x}_{\mathrm{k}}+\alpha\left(\mathrm{f}_{\mathrm{k}-1}-\mathrm{p}_{\mathrm{k}-1}\right)
$$

where $\lambda$ measures the impact of a trade on the expected value of the asset. If informed trading is possible, market makers will revise their expectation of the asset's value based on the observed order flow. The variable $f$ denotes the price of the stock on the foreign market. We assume that the market makers observe prices on the foreign market, even though they do not necessarily also observe the order flow on the foreign market. This corresponds to the actual setup of our three markets and is the same as in Domowitz et al. (1998). We add a second key part by assuming that the market makers react to the price difference by revising their expectation of the asset value. The rationale behind this assumption is that the market makers observe the different market valuation of the stock on the foreign market and conjecture that at least part of the difference is due to the fact that private information was realized on the foreign market. Thus, they adjust their expectations. ${ }^{26}$ Similar to Domowitz et al., we assume that the quotation function of market markers is public information and thus their expectations can be inferred from the quotes.

Investors arrive at the market and decide whether to trade and, if they trade, whether to buy or sell the stock. They maximize their expected utility; we assume that their utility function takes the mean-variance form. As in Domowitz et al. (1998), in order to model 
the diversification motives for trading, we assume that investors receive idiosyncratic human capital income $h_{t}$. At time $t$, the investor observes a private signal about the true value of the stock, in terms of deviation from the public expected value, $\mathrm{y}_{\mathrm{t}}$. His estimate of the stock value is thus $y_{t}+\mu_{t}$. Let $\rho^{2}$ denote the variance of this estimate. The investor thus maximizes

$$
u_{k}=\left(\mu_{k}+y_{k}+w_{k}-p_{k}\left(x_{k}\right)\right) x_{k}+E\left[h_{k}\right]-a \rho^{2} x_{k}^{2}-a \sigma_{h}^{2}
$$

by choosing $\mathrm{x}_{\mathrm{t}}$ from $\{-1,0,1\}$. The term $\mathrm{w}_{\mathrm{t}}$ stands for $-2 \operatorname{cov}\left(\mathrm{h}_{\mathrm{t}}, \mathrm{v}_{\mathrm{t}}\right)$, that is, the covariance between the investor's human capital income and the stock's fundamental value. This term captures the diversification benefits the investor yields from investing in the stock. For an investor who arrives at the market, it might be optimal not to trade $\left(\operatorname{set} \mathrm{x}_{\mathrm{t}}=0\right)$. It can be shown that the investor will not trade if $\mathrm{s}+\mathrm{a} \rho^{2}>\left|\mathrm{y}_{\mathrm{t}}+\mathrm{w}_{\mathrm{t}}\right|{ }^{27}$ Let $\varphi$ be the probability that the investor will choose not to trade upon arrival: $\varphi=\operatorname{Prob}\left[\mathrm{x}_{\mathrm{t}}=0\right]=$ $\operatorname{Prob}\left[\mathrm{s}+\mathrm{a} \rho^{2}>\left|\mathrm{y}_{\mathrm{t}}+\mathrm{w}_{\mathrm{t}}\right|\right]$.

At this point, we need to express the variance of price changes on the local market. The price change from opening to closing on the local market is

$$
p_{N}-p_{0}=\lambda \sum_{t=1}^{N} x_{t}+s x_{t}+\alpha \sum_{j=1}^{N}\left(f_{j-1}-p_{j-1}\right)
$$

\footnotetext{
${ }^{26}$ This assumption is justified by the results of Granger causality tests and error-correction model estimates, which were presented above. The London market appears to be an important place in terms of realization of information relevant for the value of the stocks.

${ }^{27}$ See the Domowitz et al. (1998) study.
} 
We are, however, interested in the variance of close-to-close price changes. In order to obtain it, we need to consider the overnight innovations on the local market $\varepsilon \sim\left(0, \sigma_{\varepsilon}{ }^{2}\right){ }^{28}$ Thus, using the properties of Poisson distribution and the assumption that the innovations, pricing errors and local price changes are independent, the variance of the close-to-close price changes is $\sigma^{2}\left(p_{N}-p_{0}+\varepsilon\right)=\left(s^{2}+2 \lambda s\right) \sigma^{2}\left(x_{N}\right)+\lambda^{2}(1-\varphi) \theta+\alpha^{2} \sigma^{2}\left(\sum_{j=1}^{N}\left(f_{j-1}-p_{j-1}\right)\right)+\sigma_{\varepsilon}^{2}$

It is worth noting that it is the variance of mispricing that increases the local market variance. The variance of $f$, the price on the foreign market, as such does not matter. This can be seen from the fact that if the two prices - on the foreign and local markets - were always the same, no additional source of volatility would exist.

Let $\Delta \mathrm{p}$ denote the change of the price on the local market and let $\Delta \mathrm{lf}$ stand for the difference between the domestic and foreign prices. We square these terms in order to obtain a proxy for the variance of the local price and the variance of the pricing error, respectively. The variance of the pricing error is used as an approximation of the term $\alpha^{2} \sigma^{2}\left(\sum_{j=1}^{N}\left(f_{j-1}-p_{j-1}\right)\right)$, which is not observable in the data. We estimate the model

$$
\begin{gathered}
\left(\Delta \mathrm{p}_{\mathrm{t}}\right)^{2}=\gamma_{0}+\gamma_{1} \mathrm{GDR}_{\mathrm{t}}+\beta_{0}\left(\Delta \mathrm{p}_{\mathrm{t}-1}\right)^{2}+\beta_{1}\left(\Delta \mathrm{p}_{\mathrm{t}-1}\right)^{2} \mathrm{GDR}_{\mathrm{t}}+ \\
+\lambda_{0} \mathrm{VOL}_{\mathrm{t}}+\lambda_{1} \mathrm{VOL}_{\mathrm{t}} \mathrm{GDR}_{\mathrm{t}}+\alpha\left(\Delta \mathrm{lf}_{\mathrm{t}}\right)^{2}+\mathrm{e}_{\mathrm{t}}
\end{gathered}
$$

where GDR $\mathrm{t}_{\mathrm{t}}$ equals 1 after GDR listing and 0 otherwise. It is worth repeating that the coefficient $\alpha$ denotes the impact of the pricing errors. Coefficients $\gamma, \beta$ and $\lambda$ with

\footnotetext{
${ }^{28}$ The overnight innovations on the foreign market impact only the variable $f$ and not $p$ directly (foreign
} 
subscript 0 denote the baseline volatility, volatility persistence and the impact of trading volume, respectively, prior to GDR listing. The same coefficients with subscript 1 measure the change in the original coefficients due to GDR listing. As mentioned above, we are able to estimate this full model only for 10 out of the 22 stocks. For the other 12 stocks, we estimate a simplified model, that is, the model specified in (7) without the GDR terms.

When estimating model (7), we encountered the endogeneity problem. The variable $\left(\Delta l f_{t}\right)^{2}$, which equals $\left(f_{t}-p_{t}\right)^{2}$, contains the current value of the local price and, since the dependent variable is $\left(\Delta \mathrm{p}_{\mathrm{t}}\right)^{2}=\left(\mathrm{p}_{\mathrm{t}}-\mathrm{p}_{\mathrm{t}-1}\right)^{2}$, the variable $\left(\Delta \mathrm{ll} \mathrm{f}_{\mathrm{t}}\right)^{2}$ is correlated with the error term $\mathrm{e}_{\mathrm{t}}$. One can solve the problem by using instrumental variables, variables that are correlated with the problem variable (here $\left.\left(\Delta \mathrm{lf}_{\mathrm{t}}\right)^{2}\right)$ but are not correlated with the error term. We use the variance of the foreign index (FTSE 100) as an instrumental variable here. It is correlated with the variance of the pricing error, but it is not correlated with the error term. In is worth noting that the index FTSE 100 does not measure the development on the SEAQ International segment of the London Stock Exchange, but rather includes the most important U.K. stocks. In fact, it would be very difficult to argue that the FTSE 100 index is influenced by price changes of emerging market companies from Central Europe, which makes it a good instrument. We also use lagged value of the price error variance as the second instrument for the current pricing-error variance. As for the estimation method, the relatively large number of observations allows us to use the Generalized Method of Moments (GMM) estimator with the above mentioned 
instruments. Standard errors were computed from a heteroscedastic-consistent matrix (White), also robust to first-order autocorrelation.

\subsection{Estimation Results}

Our results confirm that the mispricing, or more precisely its variance, is an important determinant of the local return variance. The results thus lend support to our model, which assumed that the two markets are fragmented and that investors take into account the mispricing when updating their beliefs about the fundamental price of the stock. In half of the cases, the coefficient alpha, which captures the effect of the pricing error volatility, is significant at the $5 \%$ level.

\section{$<$ Table 6 can be found in the Appendix $>$}

The baseline volatility estimates are significant and positive, which is in line with expectations. There is some evidence that it diminishes as the result of the GDR listing. We also find a significant and positive effect of volume, which is in line with both the predictions of our model and with the findings of Domowitz et al. (1998). One might argue that the effect of volume tends to diminish after the GDR listing, but the evidence is not very strong as there are also significant positive coefficients. Also, the first-order autocorrelation term is significant and positive, which implies that higher variance observations tend to be clustered. It does not change after the listing of the GDRs. The coefficient of determination varies from just $1 \%$ to as high as $69 \%$. On average, the model explains $17 \%$ of local stock price variance. 


\section{Conclusion}

The current paper investigates the information flows between cross-listed stocks by using a sample of securities from Central Europe. We focus on one of the potential problems arising from cross-listing of securities: increased variance of the local market returns after the shares are cross-listed abroad. Earlier studies attempted to explain this increased variance by order flow migration and higher baseline volatility of returns. We extend an earlier model to include another factor influencing local return variance: the pricing errors between the local and foreign markets. The excess returns and thus incentives to cross-list securities tend to be higher in the case of segmented markets, in other words, when cross-listing overcomes existing barriers. This, however, suggests that the local and foreign markets, on which the cross-listed securities are traded, are unlikely to be integrated and pricing errors might be substantial.

As the first step of our analysis, we use a Granger causality and cointegration framework to examine the information flows and co-movements between the markets. We found that substantial information flows exist between the local and London markets. The markets appear to be fragmented, since we found systematic causality patterns in daily data. Moreover, these patterns persisted over several days. The two time series of prices are cointegrated and estimation of an error-correction model suggests that arbitrage works in both directions to correct any pricing errors. The relationship between the local and London markets appears to be rather symmetric in terms of the error-correction mechanism. As for the Granger causality, we found that it runs in both directions, but the London market appears to be slightly more important, at least in terms of the number of companies for which the null hypothesis of no causality was rejected. 
Estimation of the sources of variance on the local market lends support to our model, which assumes that the investors watch and react to the difference between the local and London prices. We have thus identified another factor that needs to be considered when considering cross-listing shares abroad in an emerging market environment: the increased variance of returns that is induced by the fragmentation of the market. Our findings help explain the increased variance of returns that was reported previously. 


\section{References}

Alexander J. Gordon, Cheol S. Eun and S. Janakiramanan. 1987. "Asset Pricing and Dual Listing on Foreign Capital Markets: A Note". Journal of Finance. 42(1), pages 151158.

Alexander J. Gordon, Cheol S. Eun and S. Janakiramanan. 1988. "International Listings and Stock Returns: Some Empirical Evidence". Journal of Financial and Quantitative Analysis. 23(2), pages 135-151.

Dickey, D. and W. Fuller. 1979. "Distribution of the Estimators for Autoregressive Time Series with a Unit Root". Journal of the American Statistical Association. 74, 1979, pages $427-431$.

Domowitz, Ian, Jack Glen and Ananth Madhavan. 1998. "International Cross-Listing and Order Flow Migration”. Journal of Finance. December 1998, 53(6), pages 2001-2027.

Foerster, Stephen R. and G. Andrew Karolyi. 1999. "The Effects of Market Segmentation and Investor Recognition on Asset Prices: Evidence from Foreign Stocks Listing in the United States". Journal of Finance. June 1999, 54 (3), pages 981-1013.

Garbade, Kenneth D. and William L. Silber. 1979. "Dominant and Satellite Markets: A Study of Dually-Traded Securities". Review of Economics and Statistics, 61, pages $455-460$.

Glosten, Lawrence R. and Paul Milgrom. 1985. "Bid, Ask, and Transaction Prices in a Specialist Market with Heterogeneously Informed Agents". Journal of Financial Economics. 14, pages 71-100.

Granger, C. W. J. 1969. "Investigating Causal Relations by Econometric Models and Cross-Spectral Methods." Econometrica, 37, pages 424-438.

Hauser, Shmuel, Yael Tanchuma, and Uzi Yaari. 1998. "International Transfer of Pricing Information Between Dually Listed Stocks." Journal of Financial Research, 21, pages $139-157$.

Jayaraman, Narayanan, Kuldeep Shastri, and Kishore Tandon. 1993. "The Impact of International Cross-listings on Risk and Return: The Evidence from American Depositary Receipts". Journal of Banking and Finance. 17, pages 91-103.

Kato, Kiyoshi, Scott Linn, and James Schallheim. 1991. "Are There Arbitrage Opportunities in the Market for American Depository Receipts?" Journal of International Financial Markets, Institutions and Money. 1(1), pages 73-89.

Karolyi, G. Andrew. 1996. What Happens to Stocks that List Shares Abroad? A Survey of the Evidence and Its Managerial Implications". Working Paper, University of Western Ontario.

Lieberman, Offer, Uri Ben-Zion, and Shmuel Hauser. 1999. "A Characterization of the Price Behavior of International Dual Stocks: An Error Correction Approach". Journal of International Money and Finance. 18, pages 289-304.

Miller, P. Darius. 1999. “The Market Reaction to International Cross-Listings: Evidence from Depositary Receipts”. Journal of Financial Economics. 51, pages 103-123. 
Murphy, Austin and Sabov Zoltan. 1995. "An Analysis of Intermarket Pricing in an Embryonic Environment." Journal of International Financial Markets, Institutions and Money. 5, pages 57-72.

Wahab, Mahmoud, Malek Lashgari, and Richard Cohn. 1992. "Arbitrage Opportunities in the American Depository Receipts Market Revisited". Journal of International Financial Markets, Institutions and Money. 2(3/4), pages 97-130.

Werner, M. Ingrid and Allan W. Kleidon. 1996. "U.K. and U.S. Trading of British CrossListed Stocks: An Intraday Analysis of Market Integration". Review of Financial Studies. Summer 1996, 9(2), pages 619-664.

White, H. 1980. "A Heteroscedasticity-Consistent Covariance Matrix Estimator and a Direct Test for Heteroscedasticity”. Econometrica. 48, pages 817-838. 


\section{Appendix}

Table 1: Basic Characteristics of Cross-Listed Stocks

\begin{tabular}{|c|c|c|c|c|c|c|}
\hline Company & Number & Country & Industry & $\begin{array}{c}\text { Mkt Cap } \\
(\mathrm{mn} \text { USD })\end{array}$ & $\begin{array}{l}\text { Number } \\
\text { of days, } \\
\text { local } \\
\text { trading }\end{array}$ & $\begin{array}{c}\text { Number } \\
\text { of days, } \\
\text { GDR } \\
\text { trading }\end{array}$ \\
\hline České radiokomunikace & 1 & $\begin{array}{c}\text { Czech } \\
\text { Republic }\end{array}$ & Telecom & 1,391 & 1,321 & 577 \\
\hline $\begin{array}{l}\text { Český telecom (SPT } \\
\text { Telecom) }\end{array}$ & 2 & $\begin{array}{c}\text { Czech } \\
\text { Republic }\end{array}$ & Telecom & 6,123 & 1,342 & 571 \\
\hline Komerční banka & 3 & $\begin{array}{c}\text { Czech } \\
\text { Republic }\end{array}$ & Banking & 860 & 1,571 & 787 \\
\hline Borsodchem & 4 & Hungary & Chemicals & 381 & 1,145 & 1,170 \\
\hline Graboplast & 5 & Hungary & Miscellaneous & 45 & 1,288 & 734 \\
\hline MATAV & 6 & Hungary & Telecom & 6,631 & 714 & 714 \\
\hline MOL & 7 & Hungary & Oil/Integrated & 1,558 & 1,227 & 1,227 \\
\hline Pick Szeged & 8 & Hungary & Food/Meat & 112 & 1,288 & 605 \\
\hline Synergon & 9 & Hungary & Computers & 65 & 331 & 338 \\
\hline Tiszai Vegyi Kombinat & 10 & Hungary & Petrochemicals & 392 & 1,047 & 1,063 \\
\hline $\begin{array}{l}\text { Zalakeramia } \\
\text { Reszvenytarsasag }\end{array}$ & 11 & Hungary & Ceramic Products & 32 & 1,286 & 851 \\
\hline OTP Bank & 12 & Hungary & Banking & 1,410 & 1,288 & 1,304 \\
\hline Gedeon Richter & 13 & Hungary & Medical/Drugs & 971 & 1,288 & 1,238 \\
\hline Agora & 14 & Poland & Media/Publishing & 1,403 & 342 & 382 \\
\hline Big Bank Gdanski & 15 & Poland & Banking & 923 & 1,723 & 792 \\
\hline $\begin{array}{l}\text { Europejski Fundusz } \\
\text { Leasingowy }\end{array}$ & 16 & Poland & Leasing & 195 & 67 & 105 \\
\hline KGHM Polska Miedz & 17 & Poland & Metal/Diversified & 1,478 & 803 & 805 \\
\hline Kredyt Bank PBI & 18 & Poland & Banking & 389 & 1,578 & 694 \\
\hline Mostostal Warszava & 19 & Poland & Construction & 31 & 1,723 & 585 \\
\hline $\begin{array}{l}\text { Powszechny Bank } \\
\text { Kredytowy }\end{array}$ & 20 & Poland & Banking & 560 & 732 & 298 \\
\hline Prokom Software & 21 & Poland & Software & 543 & 652 & 698 \\
\hline Telekomunikacja Polska & 22 & Poland & Telecom & 9,867 & 451 & 458 \\
\hline
\end{tabular}

Sources: Bloomberg, company Web pages, own calculation. Note: The samples start as the stocks have been introduced to the local capital market (or as the GDRs were listed in London). The initial public offering date ranges from June 1993 to March 2000. The sample ends at the beginning of August 2000. 
Table 2: Results of the Granger Causality Test

\begin{tabular}{|c|c|c|c|c|c|c|}
\hline $\begin{array}{l}\text { Company } \\
\text { Number }\end{array}$ & $\begin{array}{c}\text { Dependent } \\
\text { Variable }\end{array}$ & $\begin{array}{c}\mathrm{H}_{0}: \mathrm{No} \\
\text { causality (F- } \\
\text { statistics) }\end{array}$ & $\begin{array}{l}\text { From London } \\
\text { to local market }\end{array}$ & $\begin{array}{c}\text { From local } \\
\text { market to } \\
\text { London }\end{array}$ & $\mathbf{N}$ & $\mathrm{R}^{\wedge} 2$ \\
\hline \multirow[t]{2}{*}{1} & Local price & $11.56^{\mathrm{a}}$ & Yes & $\mathrm{No}$ & 568 & 0.07 \\
\hline & GDR price & 1.63 & & & 568 & 0.02 \\
\hline \multirow[t]{2}{*}{2} & Local price & 1.10 & No & Yes & 558 & 0.02 \\
\hline & GDR price & $14.18^{\mathrm{a}}$ & & & 558 & 0.12 \\
\hline \multirow[t]{2}{*}{3} & Local price & $4.40^{\mathrm{a}}$ & Yes & Yes & 763 & 0.08 \\
\hline & GDR price & $12.90^{\mathrm{a}}$ & & & 763 & 0.09 \\
\hline \multirow[t]{2}{*}{4} & Local price & $10.08^{\mathrm{a}}$ & Yes & Yes & 855 & 0.05 \\
\hline & GDR price & $7.02^{a}$ & & & 855 & 0.04 \\
\hline \multirow[t]{2}{*}{5} & Local price & 1.38 & No & Yes & 632 & 0.02 \\
\hline & GDR price & $11.65^{\mathrm{a}}$ & & & 632 & 0.07 \\
\hline \multirow[t]{2}{*}{6} & Local price & $18.10^{\mathrm{a}}$ & Yes & Yes & 601 & 0.12 \\
\hline & GDR price & $3.01^{\mathrm{b}}$ & & & 601 & 0.03 \\
\hline \multirow[t]{2}{*}{7} & Local price & $15.83^{\mathrm{a}}$ & Yes & Yes & 920 & 0.08 \\
\hline & GDR price & $2.72^{b}$ & & & 920 & 0.02 \\
\hline \multirow[t]{2}{*}{8} & Local price & $9.32^{\mathrm{a}}$ & Yes & Yes & 567 & 0.04 \\
\hline & GDR price & $42.85^{\mathrm{a}}$ & & & 567 & 0.16 \\
\hline \multirow[t]{2}{*}{9} & Local price & $10.34^{\mathrm{a}}$ & Yes & Yes & 314 & 0.14 \\
\hline & GDR price & $3.70^{\mathrm{a}}$ & & & 314 & 0.16 \\
\hline \multirow[t]{2}{*}{10} & Local price & $5.16^{\mathrm{a}}$ & Yes & Yes & 763 & 0.02 \\
\hline & GDR price & $11.73^{\mathrm{a}}$ & & & 763 & 0.06 \\
\hline \multirow[t]{2}{*}{11} & Local price & $6.43^{\mathrm{a}}$ & Yes & Yes & 660 & 0.06 \\
\hline & GDR price & $14.75^{\mathrm{a}}$ & & & 660 & 0.10 \\
\hline \multirow[t]{2}{*}{12} & Local price & $14.97^{\mathrm{a}}$ & Yes & No & 980 & 0.06 \\
\hline & GDR price & 1.48 & & & 980 & 0.02 \\
\hline \multirow[t]{2}{*}{13} & Local price & $18.22^{\mathrm{a}}$ & Yes & Yes & 931 & 0.12 \\
\hline & GDR price & $4.81^{\mathrm{a}}$ & & & 931 & 0.05 \\
\hline \multirow[t]{2}{*}{14} & Local price & $7.51^{\mathrm{a}}$ & Yes & No & 335 & 0.05 \\
\hline & GDR price & 0.90 & & & 335 & 0.02 \\
\hline \multirow[t]{2}{*}{15} & Local price & $40.66^{\mathrm{a}}$ & Yes & No & 694 & 0.20 \\
\hline & GDR price & 0.82 & & & 694 & 0.05 \\
\hline \multirow[t]{2}{*}{16} & Local price & $2.79^{b}$ & Yes & Yes & 60 & 0.40 \\
\hline & GDR price & $2.94^{b}$ & & & 60 & 0.38 \\
\hline \multirow[t]{2}{*}{17} & Local price & $58.8^{\mathrm{a}}$ & Yes & No & 713 & 0.20 \\
\hline & GDR price & 1.67 & & & 713 & 0.02 \\
\hline \multirow[t]{2}{*}{18} & Local price & $34.92^{\mathrm{a}}$ & Yes & No & 953 & 0.19 \\
\hline & GDR price & 0.83 & & & 953 & 0.03 \\
\hline \multirow[t]{2}{*}{19} & Local price & $6.43^{\mathrm{a}}$ & Yes & Yes & 556 & 0.04 \\
\hline & GDR price & $11.71^{\mathrm{a}}$ & & & 556 & 0.11 \\
\hline \multirow[t]{2}{*}{20} & Local price & $6.79^{\mathrm{a}}$ & Yes & Yes & 285 & 0.14 \\
\hline & GDR price & $2.75^{b}$ & & & 285 & 0.10 \\
\hline \multirow[t]{2}{*}{21} & Local price & $19.53^{\mathrm{a}}$ & Yes & No & 623 & 0.09 \\
\hline & GDR price & 1.23 & & & 623 & 0.02 \\
\hline \multirow[t]{2}{*}{22} & Local price & $29.76^{\mathrm{a}}$ & Yes & No & 431 & 0.28 \\
\hline & GDR price & 1.76 & & & 431 & 0.03 \\
\hline
\end{tabular}

Note: ${ }^{a}$ denotes rejection of the null hypothesis at the $1 \%$ level of significance, while ${ }^{b}$ denotes rejection at the $5 \%$ significance level. 
Table 3: Basic Characteristics of Mispricing

\begin{tabular}{|c|c|c|c|c|c|c|c|c|c|c|}
\hline $\begin{array}{c}\text { Company } \\
\text { Number }\end{array}$ & $\begin{array}{c}\text { Local } \\
\text { price, } \\
\text { average }\end{array}$ & $\begin{array}{c}\text { Local } \\
\text { price, } \\
\text { volatility } \\
\text { (std.dev.) }\end{array}$ & $\begin{array}{c}\text { GDR } \\
\text { price, } \\
\text { average } \\
\text { (local } \\
\text { currency) }\end{array}$ & $\begin{array}{c}\text { GDR } \\
\text { price, } \\
\text { volatility } \\
\text { (std.dev., } \\
\text { local } \\
\text { currency) }\end{array}$ & $\begin{array}{c}\text { Absolute } \\
\text { value } \\
\text { mis- } \\
\text { pricing, } \\
\text { average }\end{array}$ & \begin{tabular}{|c|} 
As \% \\
of \\
average \\
local \\
price
\end{tabular} & $\begin{array}{c}\text { Return, } \\
\text { local } \\
\text { price, } \\
\text { average } \\
\text { (after } \\
\text { GDR } \\
\text { listing) }\end{array}$ & $\begin{array}{c}\text { Return, } \\
\text { local } \\
\text { price, } \\
\text { std.dev. } \\
\text { (after } \\
\text { GDR } \\
\text { listing) }\end{array}$ & 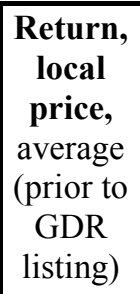 & 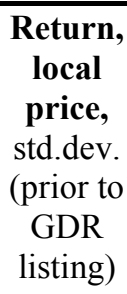 \\
\hline 1 & 1,240 & 380 & 1,249 & 367 & 17 & $1.4 \%$ & 0.0025 & 0.0299 & 0.0023 & 0.0238 \\
\hline 2 & 554 & 127 & 554 & 127 & 3 & $0.6 \%$ & 0.0011 & 0.0229 & 0.0008 & 0.0160 \\
\hline 3 & 866 & 382 & 904 & 416 & 42 & $4.9 \%$ & -0.0004 & 0.0388 & 0.0006 & 0.0191 \\
\hline 4 & 6,275 & 2,301 & 6,270 & 2,282 & 63 & $1.0 \%$ & 0.0017 & 0.0303 & - & - \\
\hline 5 & 3,859 & 3,179 & 3,876 & 3,183 & 110 & $2.8 \%$ & -0.0014 & 0.0399 & 0.0040 & 0.0205 \\
\hline 6 & 1,438 & 393 & 1,437 & 394 & 11 & $0.8 \%$ & 0.0012 & 0.0247 & - & - \\
\hline 7 & 4,187 & 1,702 & 4,190 & 1,692 & 38 & $0.9 \%$ & 0.0014 & 0.0281 & - & - \\
\hline 8 & 9,431 & 2,097 & 9,438 & 2,089 & 113 & $1.2 \%$ & 0.0000 & 0.0359 & 0.0013 & 0.0263 \\
\hline 9 & 2,740 & 503 & 2,740 & 506 & 35 & $1.3 \%$ & -0.0014 & 0.0340 & - & - \\
\hline 10 & 3,310 & 1,061 & 3,308 & 1,058 & 40 & $1.2 \%$ & 0.0014 & 0.0336 & - & - \\
\hline 11 & 4,654 & 3,260 & 4,645 & 3,254 & 89 & $1.9 \%$ & -0.0009 & 0.0380 & 0.0022 & 0.0164 \\
\hline 12 & 7,537 & 4,643 & 7,535 & 4,625 & 72 & $1.0 \%$ & 0.0025 & 0.0311 & - & - \\
\hline 13 & 12,448 & 5,733 & 12,457 & 5,699 & 118 & $0.9 \%$ & 0.0022 & 0.0343 & - & - \\
\hline 14 & 77 & 38 & 76 & 37 & 1 & $1.7 \%$ & 0.0032 & 0.0350 & - & - \\
\hline 15 & 7 & 4 & 7 & 3 & 0 & $2.4 \%$ & 0.0017 & 0.0397 & 0.0000 & 0.0317 \\
\hline 16 & 144 & 6 & 137 & 8 & 6 & $4.4 \%$ & -0.0014 & 0.0206 & - & - \\
\hline 17 & 20 & 7 & 21 & 8 & 1 & $5.4 \%$ & 0.0011 & 0.0340 & - & - \\
\hline 18 & 15 & 3 & 15 & 3 & 0 & $2.0 \%$ & 0.0013 & 0.0293 & -0.0003 & 0.0356 \\
\hline 19 & 19 & 4 & 19 & 4 & 1 & $3.6 \%$ & -0.0008 & 0.0279 & 0.0007 & 0.0416 \\
\hline 20 & 93 & 10 & 92 & 10 & 2 & $1.9 \%$ & 0.0009 & 0.0258 & -0.0003 & 0.0308 \\
\hline 21 & 144 & 45 & 143 & 44 & 3 & $2.4 \%$ & 0.0016 & 0.0367 & - & - \\
\hline 22 & 27 & 6 & 27 & 6 & 0 & $1.5 \%$ & 0.0016 & 0.0280 & - & - \\
\hline
\end{tabular}


Table 4: Testing for Unit Roots and Cointegration

\begin{tabular}{|c|c|c|c|c|c|c|c|c|}
\hline $\begin{array}{l}\text { Company } \\
\text { Number }\end{array}$ & $\begin{array}{c}\text { Local } \\
\text { price } \\
\text { (ADF test) }\end{array}$ & $\begin{array}{l}\text { GDR price } \\
\text { (ADF test) }\end{array}$ & $\begin{array}{l}\text { 1st difference } \\
\text { Local price } \\
\text { (ADF test) }\end{array}$ & $\begin{array}{l}\text { 1st difference } \\
\text { GDR price } \\
\text { (ADF test) }\end{array}$ & $\begin{array}{l}\text { Integration } \\
\text { (local price) }\end{array}$ & $\begin{array}{c}\text { Integration } \\
\text { (GDR) }\end{array}$ & $\begin{array}{c}\text { Cointegra } \\
\text { tion* }\end{array}$ & $\begin{array}{c}\text { Cointegra } \\
\text { tion*** }\end{array}$ \\
\hline $\begin{array}{ll}1 \\
\end{array}$ & & & & & $\mathrm{I}(1)$ & $\mathrm{I}(1)$ & 1.03 & $-4.57^{a}$ \\
\hline t-statistics & -2.85 & -2.74 & $-12.87^{a}$ & $-12.51^{a}$ & & & 345.9 & \\
\hline 2 & & & & & I(1) & I(1) & 1.00 & $-12.09^{a}$ \\
\hline t-statistics & -2.46 & -2.41 & $-15.33^{a}$ & $-15.58^{a}$ & & & 656.7 & \\
\hline 3 & & & & & $\mathrm{I}(1)$ & $\mathrm{I}(1)$ & 0.91 & $-4.19^{\circ}$ \\
\hline t-statistics & \begin{tabular}{|c|}
-1.87 \\
\end{tabular} & -1.96 & $-14.17^{d}$ & $-13.32^{a}$ & & & 219.3 & \\
\hline 4 & & & & & $\mathrm{I}(1)$ & $\mathrm{I}(1)$ & 1.01 & $-12.26^{a}$ \\
\hline t-statistics & -2.07 & -2.16 & $-23.13^{a}$ & $-21.5^{\mathrm{a}}$ & & & 920.8 & \\
\hline 5 & & & & & $\mathrm{I}(1)$ & $\mathrm{I}(1)$ & 1.00 & $-4.59^{a}$ \\
\hline t-statistics & -1.50 & -3.20 & $-15.13^{a}$ & $-14.56^{a}$ & & & 537.0 & \\
\hline 6 & & & & & $\mathrm{I}(1)$ & $\mathrm{I}(1)$ & 1.00 & $-6.59^{a}$ \\
\hline t-statistics & -2.32 & -2.35 & $-18.2^{a}$ & $-17.1^{a}$ & & & 638.6 & \\
\hline 7 & & & & & $\mathrm{I}(1)$ & $\begin{array}{ll}\mathrm{I}(1) \\
\end{array}$ & 1.01 & $-8.27^{a}$ \\
\hline t-statistics & -1.31 & -1.31 & $-20.9^{a}$ & $-21.58^{a}$ & & & $1,086.3$ & \\
\hline 8 & & & & & I(1) & $\mathrm{I}(1)$ & 1.00 & $-9.80^{a}$ \\
\hline t-statistics & -2.19 & -2.85 & $-14.02^{a}$ & $-11.56^{a}$ & & & 309.7 & \\
\hline 9 & & & & & I(1) & I(1) & 0.99 & $-4.86^{a}$ \\
\hline t-statistics & -1.55 & -1.21 & $-9.25^{\mathrm{a}}$ & $-12.21^{a}$ & & & 180 & \\
\hline 10 & & & & & I(1) & $\mathrm{I}(1)$ & 1.00 & $-4.87^{a}$ \\
\hline t-statistics & -1.97 & \begin{tabular}{|c|}
-1.83 \\
\end{tabular} & $-22.52^{a}$ & $-20.71^{a}$ & & & 538.6 & \\
\hline 11 & & & & & $\mathrm{I}(1)$ & $\mathrm{I}(1)$ & 1.00 & $-4.56^{a}$ \\
\hline t-statistics & -1.40 & -1.56 & $-16.6^{a}$ & $-12.60^{a}$ & & & 726.3 & \\
\hline 12 & & & & & $\mathrm{I}(1)$ & $\mathrm{I}(0)$ & 1.00 & $-7.8^{a}$ \\
\hline t-statistics & -3.29 & $-3.49^{\circ}$ & $-21.99^{d}$ & $-22.28^{a}$ & & & $1,525.2$ & \\
\hline 13 & & & & & $\mathrm{I}(1)$ & $\mathrm{I}(1)$ & 1.01 & $-6.00^{a}$ \\
\hline t-statistics & -1.65 & -2.26 & $-20.74^{a}$ & $-20.46^{a}$ & & & $1,137.7$ & \\
\hline 14 & & & & & $\mathrm{I}(1)$ & $\mathrm{I}(1)$ & 1.01 & $-6.46^{a}$ \\
\hline t-statistics & -1.83 & -2.05 & $-12.36^{a}$ & $-12.2^{a}$ & & & 412.6 & \\
\hline 15 & & & & & $\mathrm{I}(1)$ & $\mathrm{I}(1)$ & 1.01 & $-8.35^{a}$ \\
\hline t-statistics & -2.66 & -2.18 & $-19.45^{a}$ & $-19.57^{a}$ & & & 420.4 & \\
\hline 16 & & & & & $\mathrm{I}(2)$ & $\mathrm{I}(1)$ & 0.52 & -3.35 \\
\hline t-statistics & -2.06 & -2.31 & -3.38 & $-4.6^{a}$ & & & 8.9 & \\
\hline 17 & & & & & $\mathrm{I}(1)$ & $\mathrm{I}(1)$ & 0.87 & $-3.92^{\circ}$ \\
\hline t-statistics & -2.27 & -2.66 & $-18.25^{a}$ & $-15.82^{a}$ & & & 167.3 & \\
\hline 18 & & & & & $\mathrm{I}(0)$ & $\mathrm{I}(1)$ & 0.97 & $-4.55^{a}$ \\
\hline t-statistics & $-4.24^{\circ}$ & $\mid-3.07$ & $-23.99^{a}$ & $-16.46^{a}$ & & & 201.7 & \\
\hline 19 & & & & & I(1) & $\mathrm{I}(1)$ & 0.89 & $-4.90^{a}$ \\
\hline t-statistics & -1.69 & -2.28 & $-24.88^{a}$ & $-12.74^{a}$ & & & 105.6 & \\
\hline 20 & & & & & I(1) & I(1) & 0.97 & $-2.41^{a}$ \\
\hline t-statistics & -3.20 & -2.61 & $-16.33^{a}$ & $-11.45^{a}$ & & & 65.2 & \\
\hline 21 & & & & & I(1) & I(1) & 1.00 & $-4.47^{a}$ \\
\hline t-statistics & -2.15 & -2.17 & $-18.4^{a}$ & $-17.46^{a}$ & & & 215.2 & \\
\hline 22 & & & & & $\mathrm{I}(1)$ & $\mathrm{I}(1)$ & 1.00 & $-10.72^{a}$ \\
\hline t-statistics & -2.03 & -2.22 & $-16.76^{d}$ & $-14.57^{a}$ & & & 217.6 & \\
\hline
\end{tabular}

Note: ${ }^{a}$ denotes rejection of the null hypothesis (of a unit root in the case of an augmented Dickey Fuller test and of equality to zero in the case of the cointegration coefficient) at the $1 \%$ level of significance, while ${ }^{b}$ denotes rejection at the $5 \%$ significance level. *local price as the dependent variable (coefficient) **local price as the dependent variable (test statistics for residuals from the cointegration regression). 
Table 5: Error Correction Model

\begin{tabular}{|c|c|c|c|c|c|c|c|c|c|c|c|c|}
\hline \multirow[b]{2}{*}{$\begin{array}{l}\text { Company } \\
\text { Number }\end{array}$} & \multicolumn{6}{|c|}{ Change in local price as dependent variable } & \multicolumn{6}{|c|}{ Change in GDR price as dependent variable } \\
\hline & Constant & \begin{tabular}{|l} 
Change \\
of GDR \\
price
\end{tabular} & $\begin{array}{l}\text { Pricing } \\
\text { error }\end{array}$ & $\begin{array}{l}\text { Change } \\
\text { in local } \\
\text { index }\end{array}$ & $\mathbf{N}$ & $\mathbf{R}^{\wedge} \mathbf{2}$ & Constant & \begin{tabular}{|l|} 
Change \\
of local \\
price
\end{tabular} & $\begin{array}{l}\text { Pricing } \\
\text { error }\end{array}$ & $\begin{array}{l}\text { Change } \\
\text { in FTSE }\end{array}$ & $\mathbf{N}$ & $\mathbf{R}^{\wedge} \mathbf{2}$ \\
\hline 1 & -4.15 & 2.24 & $0.27^{\mathrm{a}}$ & -3.75 & 504 & 0.69 & $2.26^{\mathrm{a}}$ & $1.04^{\mathrm{a}}$ & $0.24^{\mathrm{a}}$ & 0.02 & 505 & 0.79 \\
\hline 2 & 0.05 & $0.39^{b}$ & $0.33^{\mathrm{c}}$ & $1.02^{\mathrm{a}}$ & 498 & 0.89 & -0.10 & $0.93^{a}$ & $0.97^{\mathrm{a}}$ & $0.01^{\mathrm{a}}$ & 499 & 0.92 \\
\hline t-statistics & 0.26 & 2.17 & 1.82 & 3.38 & & & -0.53 & 44.50 & 19.56 & 4.04 & & \\
\hline 3 & $-3.56^{\mathrm{a}}$ & $0.78^{\mathrm{a}}$ & $0.08^{\mathrm{a}}$ & 0.58 & 691 & 0.56 & $6.13^{b}$ & $0.90^{\mathrm{a}}$ & $0.15^{\mathrm{a}}$ & $0.05^{\mathrm{a}}$ & 693 & 0.46 \\
\hline t-statistics & -3.47 & 4.48 & 2.87 & 1.20 & & & 2.56 & 12.18 & 2.78 & 2.84 & & \\
\hline t-statistics & -0.20 & 0.37 & 0.57 & 0.00 & & & 0.91 & 9.33 & 7.46 & 3.58 & & \\
\hline 6 & 0.77 & $0.43^{\mathrm{a}}$ & $0.40^{\mathrm{a}}$ & $0.10^{\mathrm{a}}$ & 604 & 0.82 & -0.73 & $0.98^{\mathrm{a}}$ & $0.80^{\mathrm{a}}$ & $0.05^{\mathrm{a}}$ & 616 & 0.86 \\
\hline t-statistics & 1.25 & 3.50 & 3.99 & 4.26 & & & -1.33 & 29.07 & 15.84 & 5.05 & & \\
\hline 7 & -3.25 & 0.18 & $0.36^{\mathrm{a}}$ & $0.54^{\mathrm{a}}$ & 971 & 0.76 & $2.67^{\mathrm{c}}$ & $0.94^{\mathrm{a}}$ & $0.67^{\mathrm{a}}$ & $0.22^{\mathrm{a}}$ & 1007 & 0.85 \\
\hline t-statistics & -1.68 & 1.17 & 4.44 & 5.20 & & & 1.75 & 30.28 & 15.78 & 5.75 & & \\
\hline 8 & -6.89 & 0.41 & 0.33 & 0.67 & 530 & 0.67 & 6.75 & $0.89^{\mathrm{a}}$ & $0.58^{\mathrm{a}}$ & $0.18^{\mathrm{b}}$ & 536 & 0.77 \\
\hline t-statistics & -1.04 & 0.85 & 1.46 & 1.37 & & & 1.32 & 20.05 & 9.05 & 2.17 & & \\
\hline 9 & -0.73 & $1.05^{\mathrm{a}}$ & $0.85^{\mathrm{a}}$ & -0.01 & 300 & 0.77 & 0.84 & $1.03^{\mathrm{a}}$ & $0.84^{\mathrm{a}}$ & 0.00 & 300 & 0.77 \\
\hline t-statistics & -0.29 & 5.11 & 6.51 & -0.15 & & & 0.32 & 6.99 & 5.86 & 0.00 & & \\
\hline 14 & $0.41^{\mathrm{a}}$ & $0.79^{a}$ & $0.52^{\mathrm{a}}$ & $0.01^{\mathrm{c}}$ & 302 & 0.87 & $-0.35^{\mathrm{a}}$ & $0.82^{\mathrm{a}}$ & $0.52^{\mathrm{a}}$ & $0.00^{\mathrm{c}}$ & 301 & 0.87 \\
\hline t-statistics & 3.84 & 7.01 & 5.62 & 1.82 & & & -3.63 & 5.96 & 6.37 & 1.69 & & \\
\hline 15 & $0.03^{\mathrm{c}}$ & 0.03 & $0.35^{b}$ & 0.00 & 666 & 0.18 & $-0.03^{a}$ & $0.81^{\mathrm{a}}$ & $0.42^{\mathrm{a}}$ & $0.00^{\mathrm{a}}$ & 680 & 0.71 \\
\hline t-statistics & 1.90 & 0.05 & 2.46 & 1.33 & & & -2.96 & 7.96 & 5.46 & 3.31 & & \\
\hline 17 & $-0.04^{\mathrm{c}}$ & $0.39^{\mathrm{a}}$ & $0.06^{\mathrm{a}}$ & $0.01^{\mathrm{a}}$ & 676 & 0.49 & $0.04^{b}$ & $0.72^{a}$ & $0.05^{\mathrm{a}}$ & $0.00^{\mathrm{a}}$ & 689 & 0.47 \\
\hline t-statistics & -1.86 & 3.14 & 3.18 & 4.94 & & & 2.03 & 9.23 & 3.06 & 5.87 & & \\
\hline 19 & 0.04 & $1.01^{\mathrm{a}}$ & $0.19^{a}$ & 0.00 & 515 & 0.26 & -0.03 & $0.92^{\mathrm{a}}$ & $0.17^{\mathrm{a}}$ & 0.00 & 519 & 0.23 \\
\hline t-statistics & 1.58 & 4.38 & 5.34 & 0.41 & & & -1.49 & 6.70 & 5.58 & -0.34 & & \\
\hline 20 & $0.18^{\mathrm{c}}$ & $1.09^{\mathrm{a}}$ & $0.21^{\mathrm{a}}$ & 0.00 & 264 & 0.59 & $-0.26^{b}$ & $1.19^{\mathrm{a}}$ & $0.26^{\mathrm{a}}$ & 0.00 & 265 & 0.57 \\
\hline t-statistics & 1.70 & 5.95 & 3.99 & -0.38 & & & -2.00 & 4.70 & 2.99 & -0.71 & & \\
\hline 21 & 0.10 & $0.84^{\mathrm{a}}$ & $0.21^{\mathrm{a}}$ & 0.02 & 572 & 0.79 & -0.08 & $0.83^{\mathrm{a}}$ & $0.22^{\mathrm{a}}$ & $0.01^{\mathrm{a}}$ & 574 & 0.79 \\
\hline t-statistics & 0.69 & 5.91 & 4.28 & 1.32 & & & -0.59 & 16.05 & 5.14 & 4.25 & & \\
\hline 22 & $0.09^{\mathrm{a}}$ & $0.69^{\mathrm{a}}$ & $0.69^{a}$ & $0.00^{\mathrm{a}}$ & 401 & 0.69 & $-0.07^{\mathrm{a}}$ & $0.81^{\mathrm{a}}$ & $0.58^{\mathrm{a}}$ & $0.00^{\mathrm{a}}$ & 400 & 0.59 \\
\hline t-statistics & 3.95 & 5.99 & 16.05 & 2.71 & & & -2.58 & 7.73 & 6.39 & 2.97 & & \\
\hline
\end{tabular}

Note: ${ }^{a}$ denotes rejection of the null hypothesis that the coefficient equals zero at the $1 \%$ level of significance, while ${ }^{b}$ and ${ }^{c}$ denote rejection at the $5 \%$ and $10 \%$ significance levels. 
Table 6: Explaining the Volatility of Cross-Listed Securities (t-statistics in parentheses)

\begin{tabular}{|c|c|c|c|c|c|c|c|c|c|}
\hline $\begin{array}{l}\text { Company } \\
\text { Number }\end{array}$ & $\gamma_{0}$ & $\gamma_{1}$ & $\beta_{0}$ & $\beta_{1}$ & $\lambda_{0}$ & $\lambda_{1}$ & $\alpha$ & $\mathbf{N}$ & $R^{\wedge} 2$ \\
\hline 1 & $\begin{array}{r}96.42^{b} \\
(2.36)\end{array}$ & $\begin{array}{l}-223.0 \\
(-0.85)\end{array}$ & $\begin{array}{r}0.02^{\mathrm{a}} \\
(3.57)\end{array}$ & $\begin{array}{r}0.14^{\mathrm{c}} \\
(1.74)\end{array}$ & $\begin{array}{r}-0.00004 \\
(-0.64)\end{array}$ & $\begin{array}{r}0.03^{\mathrm{a}} \\
(4.27)\end{array}$ & $\begin{array}{c}0.17^{\mathrm{b}} \\
(2.24)\end{array}$ & 1,180 & 0.24 \\
\hline 2 & $\begin{array}{r}15.66^{\mathrm{a}} \\
(3.01)\end{array}$ & $\begin{array}{r}-197.3^{b} \\
(-2.43)\end{array}$ & $\begin{array}{r}0.14^{c} \\
(1.77) \\
\end{array}$ & $\begin{array}{l}-0.29^{\mathrm{a}} \\
(-2.91)\end{array}$ & $\begin{array}{r}0.0001^{\mathrm{c}} \\
(1.80)\end{array}$ & $\begin{array}{c}0.001^{\mathrm{a}} \\
(3.36)\end{array}$ & \begin{tabular}{r|}
3.00 \\
$(0.44)$ \\
\end{tabular} & 1,192 & 0.29 \\
\hline 3 & $\begin{array}{r}651.1^{\mathrm{a}} \\
(2.92)\end{array}$ & $\begin{array}{l}-71.87 \\
(-0.21)\end{array}$ & $\begin{array}{c}0.32^{b} \\
(2.36)\end{array}$ & $\begin{array}{r}-0.07 \\
(-0.51) \\
\end{array}$ & $\begin{array}{r}0.003^{b} \\
(2.27)\end{array}$ & $\begin{array}{r}0.004 \\
(1.38) \\
\end{array}$ & $\begin{array}{r}-0.008 \\
(-0.74) \\
\end{array}$ & 1,209 & 0.07 \\
\hline 4 & \begin{tabular}{r|}
0.00003 \\
$(0.11)$
\end{tabular} & n.a. & $\begin{array}{c}0.11^{\mathrm{b}} \\
(2.22)\end{array}$ & n.a. & $\begin{array}{r}0.94 \mathrm{E}-8^{\mathrm{a}} \\
(2.78)\end{array}$ & n.a. & $\begin{array}{r}1.11 \\
(1.03)\end{array}$ & 977 & 0.09 \\
\hline 5 & $\begin{array}{r}0.0003^{\mathrm{a}} \\
(6.24)\end{array}$ & $\begin{array}{r}-0.001^{\mathrm{a}} \\
(-4.18)\end{array}$ & $\begin{array}{c}0.21^{\mathrm{a}} \\
(2.75)\end{array}$ & $\begin{array}{r}0.10 \\
(0.62) \\
\end{array}$ & $\begin{array}{r}0.19 \mathrm{E}-8 \\
(1.17)\end{array}$ & $\begin{array}{r}0.92 \mathrm{E}-9 \\
(0.30)\end{array}$ & $\begin{array}{c}0.62^{\mathrm{a}} \\
(6.20)\end{array}$ & 1,185 & 0.66 \\
\hline 6 & $\begin{array}{r}0.0004^{\mathrm{a}} \\
(-2.72)\end{array}$ & n.a. & $\begin{array}{r}-0.07 \\
(-1.03)\end{array}$ & n.a. & $\begin{array}{r}0.48 \mathrm{E}-9^{\mathrm{a}} \\
(3.48)\end{array}$ & n.a. & $\begin{array}{c}2.43^{b} \\
(2.40)\end{array}$ & 641 & 0.07 \\
\hline 7 & \begin{tabular}{|c|}
-0.001 \\
$(-1.12)$ \\
\end{tabular} & n.a. & $\begin{array}{c}0.23^{b} \\
(2.39)\end{array}$ & n.a. & $\begin{array}{r}0.10 \mathrm{E}-8^{\mathrm{b}} \\
(2.36) \\
\end{array}$ & n.a. & $\begin{array}{c}2.64^{\mathrm{c}} \\
(1.92)\end{array}$ & 1,052 & 0.03 \\
\hline 8 & $\begin{array}{r}0.0004^{\mathrm{a}} \\
(3.47)\end{array}$ & $\begin{array}{r}-0.0007^{b} \\
(-2.14)\end{array}$ & $\begin{array}{c}0.43^{b} \\
(1.99)\end{array}$ & $\begin{array}{r}0.02 \\
(0.09)\end{array}$ & $\begin{array}{r}-0.14 \mathrm{E}-8 \\
(-0.12)\end{array}$ & $\begin{array}{r}0.15 \mathrm{E}-7 \\
(0.85)\end{array}$ & $\begin{array}{r}1.65^{\mathrm{a}} \\
(2.57)\end{array}$ & 1,204 & 0.69 \\
\hline 9 & $\begin{array}{r}-0.002^{b} \\
(-2.29)\end{array}$ & n.a. & $\begin{array}{r}-0.05 \\
(-0.27)\end{array}$ & n.a. & $\begin{array}{r}0.2 \mathrm{E}-07^{b} \\
(2.23)\end{array}$ & n.a. & $\begin{array}{c}8.17^{b} \\
(2.10)\end{array}$ & 309 & 0.19 \\
\hline 10 & $\begin{array}{r}0.0001 \\
(0.67) \\
\end{array}$ & n.a. & $\begin{array}{r}0.14 \\
(1.41)\end{array}$ & n.a. & $\begin{array}{r}0.2 \mathrm{E}-8^{\mathrm{a}} \\
(4.03)\end{array}$ & n.a. & $\begin{array}{r}0.44 \\
(0.90)\end{array}$ & 886 & 0.20 \\
\hline 11 & $\begin{array}{r}0.0002^{\mathrm{a}} \\
(4.99)\end{array}$ & $\begin{array}{r}-0.0003 \\
(-1.52) \\
\end{array}$ & $\begin{array}{c}0.20^{b} \\
(2.48) \\
\end{array}$ & $\begin{array}{r}0.01 \\
(0.04) \\
\end{array}$ & $\begin{array}{r}0.18 \mathrm{E}-8 \\
(0.52) \\
\end{array}$ & $\begin{array}{r}-0.15 \mathrm{E}-8 \\
(-0.33) \\
\end{array}$ & $\begin{array}{c}1.71^{\mathrm{b}} \\
(2.54)\end{array}$ & 1,150 & 0.14 \\
\hline 12 & $\begin{array}{r}-0.0003 \\
(-0.40) \\
\end{array}$ & n.a. & $\begin{array}{r}0.15^{\mathrm{a}} \\
(2.86)\end{array}$ & n.a. & $\begin{array}{r}0.57 \mathrm{E}-8^{\mathrm{a}} \\
(4.55)\end{array}$ & n.a. & $\begin{array}{r}0.86^{\mathrm{c}} \\
(1.61)\end{array}$ & 1,113 & 0.06 \\
\hline 13 & $\begin{array}{r}-0.002^{\mathrm{a}} \\
(-2.93) \\
\end{array}$ & n.a. & $\begin{array}{r}-0.03 \\
(-0.18) \\
\end{array}$ & n.a. & $\begin{array}{r}0.1 \mathrm{E}-07^{\mathrm{a}} \\
(4.82) \\
\end{array}$ & n.a. & $\begin{array}{r}7.65^{\mathrm{a}} \\
(3.49) \\
\end{array}$ & 1,113 & 0.30 \\
\hline 14 & $\begin{array}{r}0.001^{\mathrm{a}} \\
(3.99)\end{array}$ & n.a. & $\begin{array}{r}0.08 \\
(1.57)\end{array}$ & n.a. & $\begin{array}{r}0.33 \mathrm{E}-8 \\
(1.24) \\
\end{array}$ & n.a. & $\begin{array}{r}0.09 \\
(0.30)\end{array}$ & 320 & 0.03 \\
\hline 15 & $\begin{array}{r}0.001^{\mathrm{b}} \\
(2.38)\end{array}$ & $\begin{array}{r}-0.0001 \\
(-0.19)\end{array}$ & $\begin{array}{r}-0.02 \\
(-1.28)\end{array}$ & $\begin{array}{l}0.04^{\mathrm{c}} \\
(1.85)\end{array}$ & $\begin{array}{r}0.15 \mathrm{E}-8^{\mathrm{a}} \\
(2.70)\end{array}$ & $\begin{array}{r}-0.1 \mathrm{E}-8^{\mathrm{b}} \\
(-2.24)\end{array}$ & $\begin{array}{c}0.60^{\mathrm{a}} \\
(3.27)\end{array}$ & 1,327 & 0.01 \\
\hline 16 & $\begin{array}{r}0.0002^{b} \\
(2.48)\end{array}$ & n.a. & $\begin{array}{l}-0.002 \\
(-0.07)\end{array}$ & n.a. & $\begin{array}{r}-0.7 \mathrm{E}-8 \\
(-1.11)\end{array}$ & n.a. & $\begin{array}{r}0.05^{\mathrm{a}} \\
(2.66)\end{array}$ & 63 & 0.17 \\
\hline 17 & $\begin{array}{r}0.0003 \\
(1.51)\end{array}$ & n.a. & $\begin{array}{c}0.23^{\mathrm{a}} \\
(2.71)\end{array}$ & n.a. & $\begin{array}{r}0.24 \mathrm{E}-8^{\mathrm{a}} \\
(2.96)\end{array}$ & n.a. & $\begin{array}{r}0.01 \\
(0.53)\end{array}$ & 646 & 0.11 \\
\hline 18 & $\begin{array}{r}0.001^{\mathrm{a}} \\
(3.16)\end{array}$ & $\begin{array}{r}0.0002 \\
(0.96) \\
\end{array}$ & $\begin{array}{r}0.10^{\mathrm{a}} \\
(2.96) \\
\end{array}$ & $\begin{array}{r}-0.01 \\
(-0.22) \\
\end{array}$ & $\begin{array}{r}0.16 \mathrm{E}-7^{\mathrm{a}} \\
(3.39) \\
\end{array}$ & $\begin{array}{r}-0.2 \mathrm{E}-7^{\mathrm{a}} \\
(-3.37)\end{array}$ & $\begin{array}{c}0.04^{\mathrm{b}} \\
(2.12) \\
\end{array}$ & 1,246 & 0.05 \\
\hline 19 & $\begin{array}{r}0.001^{\mathrm{a}} \\
(5.11)\end{array}$ & $\begin{array}{r}-0.001^{\mathrm{a}} \\
(-2.71)\end{array}$ & $\begin{array}{r}0.02 \\
(0.73) \\
\end{array}$ & $\begin{array}{r}0.12 \\
(1.30)\end{array}$ & $\begin{array}{r}0.18 \mathrm{E}-7^{\mathrm{a}} \\
(3.90)\end{array}$ & $\begin{array}{r}-0.1 \mathrm{E}-7^{\mathrm{b}} \\
(-2.23)\end{array}$ & $\begin{array}{r}0.01 \\
(0.84)\end{array}$ & 1,327 & 0.02 \\
\hline 20 & $\begin{array}{r}0.001^{\mathrm{a}} \\
(6.36)\end{array}$ & n.a. & $\begin{array}{c}0.11^{b} \\
(1.94) \\
\end{array}$ & n.a. & $\begin{array}{r}0.35 \mathrm{E}-8 \\
(1.66) \\
\end{array}$ & n.a. & $\begin{array}{r}-0.0005 \\
(-0.13) \\
\end{array}$ & 650 & 0.02 \\
\hline 21 & $\begin{array}{r}0.0003^{\mathrm{c}} \\
(1.63)\end{array}$ & n.a. & $\begin{array}{r}0.08 \\
(1.46)\end{array}$ & n.a. & $\begin{array}{r}0.33 \mathrm{E}-7^{\mathrm{a}} \\
(3.79)\end{array}$ & n.a. & $\begin{array}{r}0.03 \\
(0.95)\end{array}$ & 608 & 0.15 \\
\hline 22 & $\begin{array}{l}-0.001 \\
(-1.45)\end{array}$ & n.a. & $\begin{array}{r}-0.01 \\
(-0.11)\end{array}$ & n.a. & $\begin{array}{r}-0.1 \mathrm{E}-8^{b} \\
(2.49)\end{array}$ & n.a. & $\begin{array}{c}1.98^{\mathrm{b}} \\
(2.18)\end{array}$ & 420 & 0.04 \\
\hline
\end{tabular}

Note: Generalized method of moments (GMM) estimates, with instruments (FTSE 100 and lagged error terms) for contemporaneous pricing errors. Standard errors were computed from a heteroscedasticityconsistent matrix (White), also robust to first-order autocorrelation. ${ }^{a}$ denotes rejection of the null hypothesis that the coefficient equals zero at the $1 \%$ level of significance, ${ }^{b} 5 \%$ significance level and ${ }^{c}$ $10 \%$ significance level. 


\section{Table 7: Individual Coefficient Estimates for Granger causality (t-statistics below coefficient estimates)}

\begin{tabular}{|c|c|c|c|c|c|c|c|c|c|c|c|c|c|}
\hline & Dep.var. & LOC -1 & LOC -2 & LOC -3 & LOC -4 & LOC -5 & LOC -6 & LI -1 & LI -2 & LI -3 & LI -4 & LI -5 & LI -6 \\
\hline \multirow[t]{4}{*}{1} & Local & $-0.19^{a}$ & $-0.22^{\mathrm{a}}$ & $-0.14^{b}$ & - & - & - & $0.32^{\mathrm{a}}$ & $0.26^{\mathrm{a}}$ & $0.14^{b}$ & - & - & - \\
\hline & & -2.83 & -3.23 & -2.20 & - & - & - & 5.18 & 3.97 & 2.26 & - & - & - \\
\hline & GDR & 0.10 & -0.08 & -0.05 & - & - & - & -0.09 & $0.15^{b}$ & 0.00 & - & - & - \\
\hline & & 1.46 & -1.14 & -0.80 & - & - & - & -1.41 & 2.09 & 0.05 & - & - & - \\
\hline \multirow[t]{4}{*}{2} & Local & 0.11 & -0.07 & 0.01 & -0.07 & -0.17 & - & -0.04 & 0.12 & -0.04 & 0.07 & 0.12 & - \\
\hline & & 0.97 & -0.48 & 0.09 & -0.54 & -1.49 & - & -0.36 & 0.88 & -0.32 & 0.49 & 1.14 & - \\
\hline & GDR & $0.89^{\mathrm{a}}$ & $0.53^{\mathrm{a}}$ & $0.47^{\mathrm{a}}$ & $0.28^{b}$ & -0.03 & - & $-0.81^{\mathrm{a}}$ & $-0.49^{a}$ & $-0.50^{\mathrm{a}}$ & $-0.28^{b}$ & -0.03 & - \\
\hline & & 8.05 & 3.84 & 3.26 & 2.03 & -0.24 & - & -7.35 & -3.60 & -3.55 & -2.11 & -0.32 & - \\
\hline \multirow{4}{*}{3} & Local & 0.04 & -0.04 & -0.02 & - & - & - & $0.21^{\mathrm{a}}$ & 0.05 & -0.02 & - & - & - \\
\hline & & 0.64 & -0.52 & -0.26 & - & - & - & 3.52 & 0.83 & -0.26 & - & - & - \\
\hline & GDR & $0.43^{\mathrm{a}}$ & $0.26^{\mathrm{a}}$ & $0.11^{b}$ & - & - & - & $-0.16^{b}$ & $-0.21^{\mathrm{a}}$ & $-0.19^{a}$ & - & - & - \\
\hline & & 5.89 & 3.37 & 1.63 & - & - & $\overline{-}$ & -2.43 & -3.00 & -2.91 & - & - & - \\
\hline \multirow[t]{4}{*}{4} & Local & $-0.32^{a}$ & $-0.21^{b}$ & $-0.20^{b}$ & $-0.28^{\mathrm{a}}$ & - & - & $0.39^{\mathrm{a}}$ & $0.25^{\mathrm{a}}$ & 0.12 & $0.28^{\mathrm{a}}$ & - & - \\
\hline & & -4.33 & -2.54 & -2.41 & -3.96 & - & - & 5.38 & 2.98 & 1.50 & 3.96 & - & - \\
\hline & GDR & $0.29^{\mathrm{a}}$ & $0.25^{\mathrm{a}}$ & 0.11 & $-0.15^{b}$ & - & - & $-0.25^{\mathrm{a}}$ & $-0.21^{b}$ & $-0.20^{b}$ & 0.14 & - & - \\
\hline & & 3.88 & 2.91 & 1.32 & -2.04 & - & - & -3.41 & -2.52 & -2.31 & 1.89 & - & - \\
\hline \multirow[t]{4}{*}{5} & Local & -0.07 & 0.02 & -0.04 & - & - & - & 0.01 & $0.09^{b}$ & 0.02 & - & - & - \\
\hline & & -1.52 & 0.35 & -0.87 & - & - & - & 0.16 & 2.02 & 0.36 & - & - & - \\
\hline & GDR & $0.26^{\mathrm{a}}$ & $0.20^{\mathrm{a}}$ & $0.11^{b}$ & - & - & - & $-0.11^{b}$ & $-0.14^{a}$ & $-0.17^{\mathrm{a}}$ & - & - & - \\
\hline & & 4.96 & 3.86 & 2.07 & - & - & - & -2.31 & -3.01 & -3.66 & - & - & - \\
\hline \multirow[t]{4}{*}{6} & Local & $-0.54^{\mathrm{a}}$ & $-0.54^{\mathrm{a}}$ & $-0.53^{a}$ & $-0.32^{\mathrm{a}}$ & - & - & $0.63^{\mathrm{a}}$ & $0.56^{\mathrm{a}}$ & $0.46^{\mathrm{a}}$ & $0.32^{\mathrm{a}}$ & - & - \\
\hline & & -6.29 & -5.40 & -5.33 & -3.78 & $\overline{-}$ & $\overline{-}$ & 7.87 & 5.85 & 4.77 & 3.87 & - & $\overline{-}$ \\
\hline & GDR & 0.13 & -0.03 & $-0.26^{b}$ & $-0.17^{c}$ & - & - & -0.03 & 0.03 & $0.21^{b}$ & 0.13 & - & - \\
\hline & & 1.42 & -0.31 & -2.40 & -1.89 & - & - & -0.38 & 0.26 & 1.97 & 1.46 & - & - \\
\hline \multirow[t]{4}{*}{7} & Local & $-0.43^{a}$ & $-0.29^{a}$ & $-0.30^{\mathrm{a}}$ & $-0.15^{b}$ & - & - & $0.52^{\mathrm{a}}$ & $0.32^{\mathrm{a}}$ & $0.23^{\mathrm{a}}$ & $0.12^{\mathrm{c}}$ & - & - \\
\hline & & -6.30 & -3.74 & -4.06 & -2.34 & - & - & 7.91 & 4.27 & 3.13 & 1.80 & - & - \\
\hline & GDR & $0.20^{\mathrm{a}}$ & $0.14^{\mathrm{c}}$ & -0.02 & 0.05 & - & - & $-0.14^{b}$ & -0.12 & -0.07 & -0.10 & - & - \\
\hline & & 2.85 & 1.81 & -0.22 & 0.68 & - & - & -2.02 & -1.45 & -0.86 & -1.48 & - & - \\
\hline \multirow[t]{4}{*}{8} & Local & 0.11 & $0.33^{\mathrm{a}}$ & - & - & - & - & -0.07 & $-0.35^{\mathrm{a}}$ & - & - & - & - \\
\hline & & 1.61 & 4.52 & - & - & - & - & -0.78 & -4.31 & - & - & - & - \\
\hline & GDR & $0.45^{\mathrm{a}}$ & $0.38^{\mathrm{a}}$ & - & - & - & - & $-0.32^{a}$ & $-0.41^{\mathrm{a}}$ & - & - & - & - \\
\hline & & 8.11 & 6.74 & - & - & - & - & -4.69 & -6.36 & - & - & - & - \\
\hline \multirow[t]{4}{*}{9} & Local & $-0.36^{\mathrm{a}}$ & $-0.28^{b}$ & $\begin{array}{l}-0.09 \\
\end{array}$ & -0.05 & - & - & $0.65^{\mathrm{a}}$ & 0.08 & $0.30^{\mathrm{a}}$ & $-0.20^{\mathrm{c}}$ & $\overline{-}$ & - \\
\hline & & -3.39 & -2.19 & -0.70 & -0.50 & - & - & 5.47 & 0.63 & 2.34 & -1.83 & - & - \\
\hline & GDR & $0.35^{\mathrm{a}}$ & 0.18 & 0.13 & 0.02 & - & - & 0.00 & $-0.33^{a}$ & 0.08 & $-0.21^{b}$ & - & - \\
\hline & & 3.76 & 1.57 & 1.22 & 0.22 & - & - & -0.02 & -2.79 & 0.74 & -2.19 & - & - \\
\hline \multirow[t]{4}{*}{10} & Local & $-0.16^{b}$ & -0.09 & 0.03 & 0.09 & - & - & $0.17^{b}$ & $0.12^{\mathrm{c}}$ & -0.08 & $-0.16^{b}$ & - & - \\
\hline & & -2.37 & -1.31 & 0.45 & 1.31 & - & - & 2.56 & 1.66 & -1.13 & -2.43 & - & - \\
\hline & GDR & $0.35^{\mathrm{a}}$ & $0.35^{\mathrm{a}}$ & $0.33^{\mathrm{a}}$ & $0.26^{\mathrm{a}}$ & - & - & $-0.35^{\mathrm{a}}$ & $-0.34^{\mathrm{a}}$ & $-0.36^{\mathrm{a}}$ & $-0.33^{\mathrm{a}}$ & - & - \\
\hline & & 5.33 & 5.09 & 4.79 & 4.13 & - & - & -5.40 & -4.78 & -5.12 & -5.14 & - & - \\
\hline \multirow[t]{4}{*}{11} & Local & $-0.19^{a}$ & $-0.14^{b}$ & $-0.25^{\mathrm{a}}$ & -0.03 & - & - & $0.23^{\mathrm{a}}$ & $0.22^{\mathrm{a}}$ & $0.12^{b}$ & $0.14^{b}$ & - & - \\
\hline & & -3.47 & -2.35 & -4.00 & -0.53 & - & - & 4.23 & 3.63 & 1.99 & 2.49 & - & - \\
\hline & GDR & $0.36^{\mathrm{a}}$ & $0.31^{\mathrm{a}}$ & 0.07 & $0.11^{\mathrm{c}}$ & - & - & $-0.22^{\mathrm{a}}$ & $-0.24^{\mathrm{a}}$ & $-0.11^{\mathrm{c}}$ & 0.02 & - & - \\
\hline & & 6.82 & 5.45 & 1.21 & 1.85 & - & - & -3.97 & -4.01 & -1.90 & 0.39 & - & - \\
\hline
\end{tabular}




\begin{tabular}{|c|c|c|c|c|c|c|c|c|c|c|c|c|c|}
\hline 12 & Local & $-0.42^{a}$ & $-0.23^{a}$ & $-0.21^{\mathrm{a}}$ & $-0.15^{b}$ & - & - & $0.52^{\mathrm{a}}$ & $0.29^{\mathrm{a}}$ & $0.16^{b}$ & $0.12^{\mathrm{c}}$ & - & - \\
\hline & & -6.22 & -3.11 & -2.92 & -2.32 & - & - & 7.66 & 3.76 & 2.14 & 1.78 & - & - \\
\hline & GDR & 0.08 & $0.16^{b}$ & 0.02 & -0.02 & - & - & 0.00 & -0.10 & -0.04 & -0.04 & - & - \\
\hline & & 1.25 & 2.11 & 0.23 & -0.33 & - & - & -0.07 & -1.28 & -0.51 & -0.60 & - & - \\
\hline \multirow[t]{4}{*}{13} & Local & $-0.40^{\mathrm{a}}$ & $-0.29^{a}$ & $-0.48^{\mathrm{a}}$ & $-0.37^{\mathrm{a}}$ & - & - & $0.61^{\mathrm{a}}$ & $0.37^{\mathrm{a}}$ & $0.40^{\mathrm{a}}$ & $0.33^{\mathrm{a}}$ & $\overline{-}$ & - \\
\hline & & -5.06 & -3.33 & -5.53 & -4.87 & - & - & 8.03 & 4.25 & 4.44 & 4.11 & - & - \\
\hline & GDR & $0.14^{\mathrm{c}}$ & 0.14 & $-0.16^{c}$ & $-0.17^{b}$ & - & - & 0.05 & -0.11 & 0.09 & $0.13^{c}$ & - & - \\
\hline & & 1.73 & 1.60 & -1.84 & -2.21 & - & - & 0.67 & -1.23 & 1.01 & 1.66 & - & - \\
\hline \multirow[t]{4}{*}{14} & Local & $-0.27^{\mathrm{a}}$ & -0.11 & - & - & - & - & $0.35^{\mathrm{a}}$ & $0.23^{b}$ & - & - & - & - \\
\hline & & -2.72 & -1.15 & - & - & - & - & 3.64 & 2.35 & - & - & - & - \\
\hline & GDR & 0.10 & 0.11 & - & - & - & - & -0.06 & 0.03 & - & - & - & - \\
\hline & & 1.01 & 1.14 & - & - & - & - & -0.60 & 0.30 & - & - & - & - \\
\hline \multirow[t]{4}{*}{15} & Local & $-0.41^{\mathrm{a}}$ & $-0.25^{\mathrm{a}}$ & $-0.31^{\mathrm{a}}$ & $-0.10^{b}$ & - & - & $0.56^{\mathrm{a}}$ & $0.24^{\mathrm{a}}$ & $0.26^{\mathrm{a}}$ & $0.29^{\mathrm{a}}$ & - & - \\
\hline & & -7.84 & -4.74 & -5.79 & -2.04 & - & - & 12.15 & 4.74 & 5.06 & 5.81 & - & - \\
\hline & GDR & 0.04 & 0.05 & -0.02 & 0.07 & - & - & $0.10^{\mathrm{c}}$ & -0.02 & -0.09 & 0.13 & - & - \\
\hline & & 0.70 & 0.86 & -0.36 & 1.20 & - & - & 1.90 & -0.30 & -1.50 & 2.22 & - & - \\
\hline \multirow[t]{4}{*}{16} & Local & 0.13 & -0.15 & $0.34^{b}$ & 0.13 & -0.24 & -0.02 & $0.29^{c}$ & -0.07 & 0.12 & $-0.38^{a}$ & 0.10 & 0.15 \\
\hline & & 0.80 & -0.87 & 2.11 & 0.79 & -1.56 & -0.15 & 1.97 & -0.50 & 0.87 & -2.82 & 0.60 & 1.01 \\
\hline & GDR & 0.06 & -0.14 & $0.46^{\mathrm{a}}$ & 0.22 & -0.07 & $-0.21^{\mathrm{c}}$ & $0.31^{\mathrm{c}}$ & 0.06 & -0.09 & $-0.38^{\mathrm{a}}$ & 0.18 & 0.23 \\
\hline & & 0.34 & -0.77 & 2.73 & 1.32 & -0.43 & -1.90 & 1.99 & 0.46 & -0.68 & -2.69 & 1.07 & 1.43 \\
\hline \multirow[t]{4}{*}{17} & Local & $-0.44^{\mathrm{a}}$ & $-0.22^{a}$ & $-0.14^{\mathrm{a}}$ & - & - & - & $0.55^{\mathrm{a}}$ & $0.26^{\mathrm{a}}$ & $0.14^{\mathrm{a}}$ & - & - & - \\
\hline & & -9.14 & -4.31 & -3.16 & - & - & - & 12.93 & 5.31 & 2.93 & - & - & - \\
\hline & GDR & $-0.11^{b}$ & 0.00 & -0.03 & - & - & - & $0.16^{\mathrm{a}}$ & 0.04 & -0.02 & - & - & - \\
\hline & & -2.05 & 0.03 & -0.53 & - & - & - & 3.41 & 0.79 & -0.33 & - & - & - \\
\hline \multirow[t]{4}{*}{18} & Local & $-0.33^{a}$ & $-0.29^{a}$ & $-0.19^{a}$ & $-0.13^{a}$ & $\overline{-}$ & - & $0.52^{\mathrm{a}}$ & $0.31^{\mathrm{a}}$ & $0.16^{\mathrm{a}}$ & $0.21^{\mathrm{a}}$ & - & - \\
\hline & & -6.17 & -5.16 & -3.49 & -2.68 & - & - & 11.23 & 6.00 & 3.03 & 4.19 & - & - \\
\hline & GDR & -0.01 & -0.09 & -0.09 & -0.05 & - & - & 0.05 & $0.16^{b}$ & 0.00 & $0.16^{\mathrm{a}}$ & - & - \\
\hline & & -0.20 & -1.46 & -1.39 & -0.87 & - & - & 0.95 & 2.55 & -0.02 & 2.70 & - & - \\
\hline \multirow[t]{4}{*}{19} & Local & -0.06 & -0.01 & 0.00 & - & - & - & $0.24^{\mathrm{a}}$ & 0.09 & -0.07 & - & - & - \\
\hline & & -1.16 & -0.11 & 0.01 & - & - & - & 3.94 & 1.52 & -1.24 & - & - & - \\
\hline & GDR & $0.21^{\mathrm{a}}$ & $0.13^{\mathrm{a}}$ & 0.02 & - & - & - & 0.05 & 0.01 & $-0.12^{\mathrm{a}}$ & - & - & - \\
\hline & & 5.46 & 3.15 & 0.62 & - & - & - & 1.05 & 0.27 & -2.68 & - & - & - \\
\hline \multirow[t]{4}{*}{20} & Local & $-0.26^{\mathrm{a}}$ & $-0.39^{\mathrm{a}}$ & $-0.22^{b}$ & -0.05 & $-0.23^{\mathrm{a}}$ & - & $0.50^{\mathrm{a}}$ & $0.32^{\mathrm{a}}$ & $0.22^{b}$ & 0.02 & $0.19^{\mathrm{c}}$ & - \\
\hline & & -2.83 & -3.80 & -2.13 & -0.48 & -2.49 & - & 5.18 & 3.02 & 2.02 & 0.16 & 1.90 & - \\
\hline & GDR & $0.23^{\mathrm{a}}$ & -0.05 & 0.04 & 0.01 & $-0.17^{b}$ & - & 0.06 & -0.03 & -0.06 & -0.07 & $0.17^{\mathrm{c}}$ & - \\
\hline & & 2.61 & -0.50 & 0.43 & 0.12 & -2.01 & - & 0.66 & -0.27 & -0.63 & -0.75 & 1.87 & - \\
\hline \multirow[t]{4}{*}{21} & Local & $-0.28^{\mathrm{a}}$ & $-0.29^{\mathrm{a}}$ & -0.10 & - & - & - & $0.36^{\mathrm{a}}$ & $0.41^{\mathrm{a}}$ & 0.06 & - & - & - \\
\hline & & -4.46 & -4.47 & -1.53 & - & - & - & 5.86 & 6.18 & 0.85 & - & - & - \\
\hline & GDR & $0.12^{\mathrm{c}}$ & 0.01 & 0.03 & - & - & - & -0.05 & 0.09 & -0.08 & - & - & - \\
\hline & & 1.86 & 0.20 & 0.41 & - & - & - & -0.78 & 1.39 & -1.19 & - & - & - \\
\hline \multirow[t]{4}{*}{22} & Local & $-0.51^{\mathrm{a}}$ & $-0.59^{a}$ & $-0.34^{\mathrm{a}}$ & $-0.27^{\mathrm{a}}$ & $\begin{array}{l}-0.09 \\
\end{array}$ & - & $0.69^{\mathrm{a}}$ & $0.51^{\mathrm{a}}$ & $0.41^{\mathrm{a}}$ & $0.31^{\mathrm{a}}$ & $0.11^{\mathrm{c}}$ & - \\
\hline & & -7.55 & -7.66 & -4.35 & -3.52 & -1.56 & - & 11.79 & 6.87 & 5.41 & 3.90 & 1.66 & - \\
\hline & GDR & $0.15^{\mathrm{c}}$ & 0.01 & $0.19^{b}$ & 0.03 & 0.04 & - & -0.04 & $\begin{array}{l}-0.01 \\
\end{array}$ & $-0.18^{b}$ & -0.09 & $\begin{array}{l}-0.08 \\
\end{array}$ & - \\
\hline & & 1.83 & 0.07 & 2.03 & 0.28 & 0.52 & - & -0.57 & -0.17 & -2.03 & -0.95 & -0.94 & - \\
\hline
\end{tabular}

Note: ${ }^{a}$ denotes rejection of the null hypothesis that the coefficient equals zero at the $1 \%$ level of significance and ${ }^{b}$ at the $5 \%$ significance level. LOC denotes the price on the local market, while LI stands for the GDR price in London. 
Table 8: Comparison of volatility of the cross-listed stocks and market indices

\begin{tabular}{|c|c|c|c|c|c|c|}
\hline $\begin{array}{l}\text { Company } \\
\text { Number }\end{array}$ & $\begin{array}{l}\text { Average local } \\
\text { price before } \\
\text { GDR listing }\end{array}$ & $\begin{array}{c}\text { Standard } \\
\text { deviation of } \\
\text { local price } \\
\text { before GDR } \\
\text { listing }\end{array}$ & $\begin{array}{c}\text { Variation } \\
\text { coefficient } \\
\text { before GDR } \\
\text { listing }\end{array}$ & $\begin{array}{l}\text { Average local } \\
\text { price after } \\
\text { GDR listing }\end{array}$ & $\begin{array}{c}\text { Standard } \\
\text { deviation of } \\
\text { local price } \\
\text { after GDR } \\
\text { listing }\end{array}$ & $\begin{array}{l}\text { Variation } \\
\text { coefficient } \\
\text { after GDR } \\
\text { listing }\end{array}$ \\
\hline 1 & 349.8 & 106.9 & 0.31 & 1240.4 & 380.1 & 0.31 \\
\hline 2 & 339.4 & 57.7 & 0.17 & 554.0 & 126.8 & 0.23 \\
\hline 3 & $1,930.3$ & 371.3 & 0.19 & 866.0 & 381.6 & 0.44 \\
\hline 5 & $5,522.3$ & $3,374.7$ & 0.61 & $3,858.7$ & $3,179.3$ & 0.82 \\
\hline 8 & $9,961.7$ & $3,615.9$ & 0.36 & $9,431.2$ & $2,096.6$ & 0.22 \\
\hline 11 & $5,845.9$ & $1,842.6$ & 0.32 & $4,653.5$ & $3,259.9$ & 0.70 \\
\hline 15 & 2.6 & 1.1 & 0.43 & 6.7 & 3.5 & 0.53 \\
\hline 18 & 8.3 & 2.0 & 0.24 & 15.1 & 3.1 & 0.21 \\
\hline 19 & 15.2 & 8.4 & 0.55 & 18.8 & 3.7 & 0.19 \\
\hline 20 & 80.1 & 11.9 & 0.15 & 93.1 & 10.4 & 0.11 \\
\hline
\end{tabular}

\begin{tabular}{|c|c|r|r|r|r|r|}
\hline $\begin{array}{c}\text { Company } \\
\text { Number }\end{array}$ & $\begin{array}{c}\text { Average } \\
\text { market index } \\
\text { before GDR } \\
\text { listing }\end{array}$ & $\begin{array}{c}\text { Standard } \\
\text { deviation of } \\
\text { market index } \\
\text { before GDR } \\
\text { listing }\end{array}$ & $\begin{array}{c}\text { Variation } \\
\text { coefficient } \\
\text { market index) } \\
\text { before GDR } \\
\text { listing }\end{array}$ & $\begin{array}{c}\text { Average } \\
\text { market index } \\
\text { after GDR } \\
\text { listing }\end{array}$ & $\begin{array}{c}\text { Standard } \\
\text { deviation of } \\
\text { market index } \\
\text { after GDR } \\
\text { listing }\end{array}$ & $\begin{array}{c}\text { Variation } \\
\text { coefficient } \\
\text { (market index) } \\
\text { after GDR } \\
\text { listing }\end{array}$ \\
\hline 1 & 505.58 & 48.75 & 0.10 & 479.06 & 85.02 & 0.18 \\
\hline 2 & 505.14 & 48.77 & 0.10 & 479.33 & 85.45 & 0.18 \\
\hline 3 & 507.40 & 54.29 & 0.11 & 484.97 & 75.05 & 0.15 \\
\hline 5 & $4,048.3$ & $2,054.5$ & 0.51 & $7,412.3$ & $1,435.4$ & 0.19 \\
\hline 8 & $4,723.2$ & $2,365.5$ & 0.50 & $7,342.9$ & $1,531.1$ & 0.21 \\
\hline 11 & $3,197.0$ & $1,353.6$ & 0.42 & $7,375.0$ & $1,361.2$ & 0.18 \\
\hline 15 & $1,127.2$ & 351.7 & 0.31 & $1,623.8$ & 309.9 & 0.19 \\
\hline 18 & $1,189.3$ & 370.3 & 0.31 & $1,624.4$ & 327.6 & 0.20 \\
\hline 19 & $1,232.0$ & 383.9 & 0.31 & $1,617.1$ & 345.8 & 0.21 \\
\hline 20 & $1,465.8$ & 230.3 & 0.16 & $1,839.1$ & 205.6 & 0.11 \\
\hline
\end{tabular}

\begin{tabular}{|c|r|r|}
\hline $\begin{array}{c}\text { Company } \\
\text { Number }\end{array}$ & $\begin{array}{c}\text { Variation coefficient } \\
\text { after GDR } \\
\text { listing/variation } \\
\text { coefficient after GDR } \\
\text { listing (local price) }\end{array}$ & $\begin{array}{c}\text { Variation coefficient } \\
\text { after GDR } \\
\text { listing/variation } \\
\text { coefficient after GDR } \\
\text { listing (market index) }\end{array}$ \\
\hline 1 & 1.00 & 1.84 \\
\hline 2 & 1.35 & 1.85 \\
\hline 3 & 2.29 & 1.45 \\
\hline 5 & 1.35 & 0.38 \\
\hline 8 & 0.61 & 0.42 \\
\hline 11 & 2.22 & 0.44 \\
\hline 15 & 1.23 & 0.61 \\
\hline 18 & 0.87 & 0.65 \\
\hline 19 & 0.35 & 0.69 \\
\hline 20 & 0.75 & 0.71 \\
\hline
\end{tabular}

Note: Variation coefficient is defined as the standard deviation over the average of a random variable. We used the same indices that are described in the text above as an approximation of the market indices: PX50 for the Czech market, BUX for Hungary and WIG for Poland. 